\title{
Financial Harmonization and Industrial Growth \\ : Evidence from the European Union
}

\author{
Zeynep Ozkok \\ St. Francis Xavier University, Antigonish, Canada
}

\begin{abstract}
This study analyzes the growth effects of the Financial Services Action Plan of the European Commission, a set of directives that aim to harmonize European financial markets. Using a panel of 25 countries and 30 industries, we find that the standard specification predicts lower growth due to harmonization, though the negative effect is mitigated for industries that depend more on external finance. Controlling for the relative timing of the adoption, harmonization is shown to have a positive effect on growth. This finding is robust to including further controls, to splitting the sample into subgroups of countries, and to extending the model to a dynamic setting.
\end{abstract}

JEL Classifications: F15, F36, F55, G15, G28, K4, O4

Keywords: Financial Integration, Legal, Regulatory Harmonization, External Finance Dependence, European Union, FSAP

\footnotetext{
* Corresponding Author: Zeynep Ozkok; St. Francis Xavier University, Department of Economics, PO Box 5000, Antigonish, Nova Scotia, B2G 2W5, Canada, Tel: +19028675855, Fax: +19028673610, E-mail: zozkok@stfx.ca. 


\section{Introduction}

The European Union (EU), with the intention of integrating countries and creating a unified European financial market, has implemented two important measures over the last two decades. The first measure is, of course, the introduction of the euro. Since its establishment in 1999, the euro has grown to be a leading currency in the world's financial markets, and has contributed significantly to unifying Europe's financial markets. The second, less well known measure is the so-called Financial Services Action Plan (FSAP), which aims at harmonizing European financial markets through the imposition and adoption of regulatory and legislative frameworks.

According to Hartmann et al. (2003, 34) and Kalemli-Ozcan et al. (2013), with the strategic objectives of ensuring "a single EU market for wholesale financial services," creating "open and secure retail markets, and state-of-the-art prudential rules and supervision," and establishing "wider conditions for an optimal single financial market," the FSAP intends to harmonize and reduce the costs of cross-border financial intermediation and transactions. The FSA (2003) and London Economics (2002) reiterate the European Commission's argument that financial harmonization should increase economic growth by reducing the cost of cross-border financial business. However, to date, there have been no in-depth studies on the outcomes of the FSAP on growth. This study addresses this issue by examining the effect of the FSAP measures on growth across countries, from an industry perspective. Given that different industries depend on external finance to varying degrees, it is likely that the impact of the FSAP on growth will be industry-dependent. Therefore, we examine the effects of the FSAP financial harmonization policies on industrial growth using a panel of $25 \mathrm{EU}$ member states and 30 industries for the period 1971 2007.

Based on the view of the European Commission, we would expect harmonization to have a positive impact on growth rates across industries and countries. However, after regressing growth on financial harmonization, we find a negative impact. Nevertheless, we do find that this negative effect is mitigated in industries that depend more on external finance than others do. There may be several reasons for the negative effect of harmonization on growth. First, while harmonization may refer to integration, thus lowering the cost of cross-country financial activity, it may also refer to uniformity, often implying adoption costs, without clear benefits. For example, Boyfield et al. (2006) have reported that the additional costs faced by the British economy after the implementation 
of the FSAP measures amounted to more than 14 billion pounds. Therefore, we classify the different directives of the FSAP into those aimed primarily at uniformity, those aimed primarily at integration, and those that do not fall under either of the first two categories. Consistent with our prior, the directives that focus on uniformity continue to have a significant negative effect, while those that focus on integration cease to have a significant effect.

Second, the timing of the adoption of the FSAP directives may be crucial to determining their effects on growth. In particular, being an early adopter may not be advantageous, because the country would bear the costs of adoption, without reaping the benefits of harmonization, since the other countries would be lagging behind. After controlling for the relative timing of adoption in our estimations, we find that harmonization has a beneficial effect on growth. In addition, we find evidence of early adoption having a negative impact on growth. We then carry out a number of robustness checks to examine whether our main result (i.e., harmonization has a positive effect on growth, and the relative timing of adoption has a negative effect) still holds. The results are mostly robust to splitting our sample into EU-15, Euro, and non-EU-15 countries, as well as to introducing additional control variables, such as legal and governmental measures, and financial and stock market development indicators. Lastly, we analyze the consistency of our benchmark model using a dynamic panel Generalized Method of Moments (GMM) model. The dynamic Arellano-Bond model (1991) derives similar conclusions, reporting that harmonization is positively significant on industrial growth when the harmonization difference measure is included in the estimations.

Our study is related to different strands of the literature. The first strand is the literature on the effects of deregulation on growth and volatility. For example, Jayaratne and Strahan $(1996,1997)$ and Strahan (2002) study the impact of branching deregulation and interstate banking on growth. Their results reveal that following state-level branching deregulation, real per-capita economic growth across the United States (US) increased significantly. Policy changes that allow for higher integration, better bank monitoring, and screening across states are found to be a possible explanation. In a more recent study, De Avila (2003) examined the effects of financial deregulation in Europe, showing that the lifting of capital controls and harmonizing of banking laws enhanced the growth rates of European economies. Harmonization is found to be beneficial for growth through an increase in the level and efficiency of financial intermediation, whereas the liberalization of capital controls increases growth by improving financial intermediation. In contrast to our study, De Avila (2003) is limited to a cross-country analysis and, therefore, does 
not take into account cross-industry variations. In addition, his study focuses on the European Commission directives on banking integration that were established prior to the FSAP.

The second strand in the literature is that on the link between dependence on external finance and growth. An important work in this area is that of Rajan and Zingales (1998), who study the role of external finance on industrial growth. The authors find that financial development influences the rate of growth of industries by reducing the cost of external finance. This effect is especially strong in firms with a greater dependence on external finance. Rajan and Zingales (1998) show that industries that require higher levels of external finance develop faster in countries with established financial markets. Similarly, Gupta and Yuan (2003), using the Rajan and Zingales external finance dependence measure, demonstrate that stock market liberalizations lead to higher growth rates in industries that depend more heavily on external finance. Given this evidence, we are interested in whether the benefits of financial harmonization are greater in those industries with a greater dependence on external finance. Thus, our analysis combines the literature on financial deregulation and on external finance dependence.

The third strand includes works that have studied the FSAP measures. Here, KalemliOzcan et al. (2013) analyze the link between financial integration and business cycle synchronization. The authors' analysis, using bilateral panel instrumental variables to link legislative harmonization policies to output synchronization, depicts a negative relationship for the country-pairs in their sample. In an attempt to examine the euro's effect on financial integration Kalemli-Ozcan et al. (2010) reveal that the legislativeregulatory harmonization policies in financial markets established under the FSAP contribute to cross-border lending, despite these policies' inability to explain the euro's impact on financial integration. Lastly, Ozkok (2016) considers the impact of the FSAP financial harmonization policies on financial development, and finds a positive link. However, none of these studies assess the impact on growth, or use industrial data.

In contrast to the results of prior studies, an important finding is that controlling for the relative timing of adoption is essential. Clearly, adopting harmonization measures when others do not does not amount to true harmonization. We expect early adopters to face more of the costs and fewer of the benefits in comparison to late adopters. Our results indicate that not controlling for the relative timing of adoption leads to a serious omitted variable bias. Indeed, failing to control for this important variable changes the impact of harmonization on growth from being positive to negative. 
The rest of the paper is structured as follows. In the next section, we explain our data, and Section III discusses the empirical model. Then, Section IV describes our results and several robustness checks. Lastly, Section V concludes the paper.

\section{Data}

Our data come from a variety of sources. The panel consists of annual industrylevel data from 25 European economies over the period 1971 2007. ${ }^{1}$ The countries in our analysis are Austria, Belgium, Cyprus, Czech Republic, Denmark, Estonia, Finland, France, Germany, Greece, Hungary, Ireland, Italy, Latvia, Lithuania, Luxembourg, Malta, the Netherlands, Poland, Portugal, Slovakia, Slovenia, Spain, Sweden, and the United Kingdom (UK). ${ }^{2}$ Below, we discuss the indicators employed in the analysis in further detail.

\section{A. Measure of industrial growth}

The industrial data for growth come from the EU KLEMS (capital, K; labor, L; energy, E; materials, M; and service, S inputs) Growth and Productivity Accounts data set. ${ }^{3}$ We use industrial data for 25 EU member countries for 30 industries (sectors). Having industry-level data is essential to exploiting cross-industry variations in external finance dependence, while cross-country variations are important to identifying the effects of harmonization on growth. The period covered in the EU KLEMS data set is 1970 2007 for EU-15 countries, and 1995 2007 for the 10 newer EU member states. From the EU KLEMS data set, we use gross value-added in constant euros. Gross valueadded growth in country $i$, industry $s$, and time $t$ is defined as:

\footnotetext{
${ }^{1}$ Our analysis focuses on the impact of the FSAP measures on growth by examining data prior to the global financial crisis. By doing so we hope to analyze the immediate effect of the FSAP directives on growth, without the influence of the crisis or the contagion experienced by the European countries.

2 Our panel has three dimensions: countries $(i)$, industries (sectors) $(s)$, and time $(t)$. Most of our regressions are estimated based on a sample of 17,380 observations.

${ }^{3}$ The EU KLEMS data are available at: The EU KLEMS Growth and Productivity Accounts November 2009 Release. EU KLEMS http://www.euklems.net/. For more information, please refer to Timmer and Van Moergastel et al. (2007) and Timmer et al. (2007).
} 


$$
G V A G R O_{i, s, t}=\log \left(G V A_{i, s, t}\right)-\log \left(G V A_{i, s, t-1}\right)
$$

where $G V A_{i, s, t}$ is the gross value-added in country $i$, industry $s$, and time $t$.

\section{B. Measure of financial harmonization}

The harmonization measures used in our analysis are based on the FSAP. As Kalemli-Ozcan et al. $(2010,79)$ emphasize, the FSAP was launched by the European Union and the European Commission at the end of 1998 as a major five-year program with the goals of establishing "a single EU wholesale market for financial services, open and secure retail markets, and state-of-the-art prudential and supervisory regulations." According to the HM Treasury, The Financial Services Authority, and the Bank of England (2004a, 2004b), a single wholesale market should, in principle, allow for higher levels of finance to be raised across the EU. Furthermore, open and secure retail financial services markets should provide customers with a safer and cheaper integrated financial market, reducing charges on cross-border payments, removing barriers to retail financial services, and allowing for a larger scale of electronic commerce to take place across the EU. Then, state-of-the-art prudential rules and supervision should offer faster changes in the regulatory environment, benefiting customers in financial services.

Malcolm et al. (2009) note that the FSAP aims to remove barriers to entry in the financial sector, increase competition, and harmonize information. However, just like any other country-level legislative measure, the FSAP comes with costs and benefits. Boyfield et al. (2006) state that the benefits include increasing investment opportunities in securities markets across borders, easing the framework for investment firms, augmenting internalization, and stimulating competition between banks, thus, reducing the cost of trading and the cost of capital. Other benefits include increasing investor confidence, market liquidity, and the free flow of capital, allowing for more transparency and greater competition. The costs consist of compliance costs due to complexity, the possibility of creating barriers to entry for smaller firms, costs associated with executing the directives, and costs of implementing these directives across countries. According to the European Commission (2005), the goal of the FSAP is to form a unified financial market that can act as an essential element for growth, employment, and improved

\footnotetext{
${ }^{4}$ While most of the growth literature uses log differences to approximate growth rates, the deregulation literature often uses the direct ratio of $G V A_{i, s, t} / G V A_{i, s, t-1}$. However, using this alternative measure does not change our results qualitatively.
} 
competition in the overall European system. If so, the FSAP should have had a positive impact on growth. Thus, one of the aims of this study is to explore whether this is indeed the case.

Kalemli-Ozcan et al. (2013) state that the FSAP consists of 29 legislative acts, 27 directives, and two regulations in corporate law, banking, payment systems, and corporate governance. The most important of these are the 27 directives, which will be the focus of our analysis. The directives amend previous laws, replace out-of-date proposals, or offer new legislative measures for the EU member countries. According to Kalemli-Ozcan et al. (2013), by 2003, the European Commission has passed 21 of the 27 FSAP directives, with the remaining six being passed into legislation between 2004 and 2006. With the last FSAP directives being implemented in 2006, our analysis focuses on the adoption period of all these measures.

Kalemli-Ozcan et al. (2013) note that, unlike EU regulations, which are enforceable across countries immediately after their announcement, the FSAP directives are enforceable only after the member states pass legislation that adopts the EU law domestically. According to the HM Treasury, The Financial Services Authority, and the Bank of England (2003), the implementation stage of the FSAP directives involves the European Commission's proposal on legislative directives and regulations, which then have to be adopted by a "co-decision" of the Council of Ministers of the Member States and the European Parliament. The FSAP directives are incorporated into the national law of each EU member state, either as new laws or as amendments to existing laws, within 18 to 24 months of their original date of publication. The implementation process of the FSAP directives includes three stages: transposition of the EU legislation into national law, adjustments for necessary arrangements, and ensuring that the newly adopted regulations are working effectively and efficiently. Owing to differences across countries in terms of modifying their existing internal institutional structures and frameworks to adopt the EU law (and to their discretion as to when to adopt these directives), the transposition of the FSAP directives may take several years. This creates variation in the dates of implementation of these directives among the various countries. ${ }^{5}$ For example, Kalemli-Ozcan et al. $(2010,2013)$ show that the 1998 Settlement Finality Directive

\footnotetext{
5 The member states are given a time frame in which to transpose the directives into national law. However, some countries do not follow the timing of the FSAP directives set by the European Commission. This could occur as a result of parliamentary delays, opposition from business within the countries, difficulties in removing or altering existing laws, and possible technical obstacles. There are sanctions to ensure compliance of the member states in terms of adopting the directives. By the former Article 171 (now Article 228) of the European Treaty and Article 143 of the Euratom Treaty, the European Commission can impose tailored sanctions, depending on the severity of noncompliance.
} 
(1998/26/EC) of the FSAP, under the securities category, was implemented into domestic law in Austria, Belgium, Finland, Germany, Ireland, the Netherlands, Spain, and the UK within a year of its circulation. However, France, Italy, and Luxembourg did not adopt this directive until 2001, while Cyprus, Czech Republic, Hungary, Latvia, Lithuania, and Poland had not transposed the directive until the end of our sample period. It is this cross-country variation in the timing of the adoption of the directives that enables us to identify their effect on growth.

We assemble harmonization indices for EU countries based on when they adopted the FSAP directives. Following the methodology of Kalemli-Ozcan et al. (2010), we construct country and time-variant and industry-invariant indices of harmonization that summarize the information provided by the 27 FSAP directives. In particular, for each country and each directive, we define a dummy variable that takes the value one from the date when the country transposed the directive into national law, and zero otherwise. Following Kalemli-Ozcan et al. (2010, 2013), we sum the 27 directives to create the next variable, $l e x_{i, t}$, as follows:

$$
\text { lex }_{i, t}=\sum_{k=1}^{27} \text { Directives }_{i, t}^{k} \text {. }
$$

Then, we construct our financial harmonization index, as follows:

$$
\text { Harmonization }_{i, t}=\ln \left(1+\operatorname{lex}_{i, t}\right) \text {, }
$$

where $k$ represents the 27 directive dummies, $i$ represents a country, and $t$ denotes time, in years. Following Kalemli-Ozcan et al. (2010), we use the logarithmic transformation of the sum of the directives per country. Then, again following KalemliOzcan et al. (2010), for robustness, we construct two different indices that include the initial 21 directives put into force by the European Commission before the official completion of the FSAP, and the seven directives that correspond to the banking initiatives of the FSAP. ${ }^{6}$

\footnotetext{
${ }^{6}$ The first harmonization index includes 21 directives, excluding those implemented prior to 2004 . The second index highlights the importance of the seven banking directives of the FSAP.
} 


\section{Measure of external finance dependence}

One of the aims of our model is to examine how the effect of harmonization on growth is mediated by an industry's dependence on external finance. Following Rajan and Zingales (1998), we apply a measure of an industry's dependence on external funds in the US to our European sample. The external finance dependence measure is calculated from the external financing needs of US companies during the 1970s, using data from Compustat. The measure concentrates on the amount of desired investment that cannot be financed through internal cash flows within the same company. The external finance dependence measure for a firm is constructed as:

$$
\operatorname{exffirm}_{s, t}=\frac{\operatorname{capexp}_{s, t}-c f o_{s, t}}{c \operatorname{capexp}}
$$

where exffirm ${ }_{s, t}$ is the external finance dependence measure, capexp denotes capital $_{s, t}$ expenditure, and $c f o_{s, t}$ is the cash flow from operations of a firm in industry $s$. In order to obtain the firm's overall dependence on external finance in the 1970s, Rajan and Zingales (1998) sum the external finance measure over 10 years (from 1970 to 1980), and then divide this by the sum of capital expenditure over the same period. To obtain a measure of finance dependence at the sectoral level, $\operatorname{exf}_{s}$, Rajan and Zingales (1998) use the industry median. By doing so, they reduce the effects of outliers and temporal fluctuations.

Applying the US industry measures of external finance dependence to the corresponding European industries is reasonable if, as argued by Rajan and Zingales (1998), there is a technological reason for some industries depending more on external finance than others do. For example, if the machinery industry requires a larger initial scale and a longer gestation period before the admittance of cash flows into the sector than the textile industry in the US, this would also be true for the two industries in France. Given the assumption that these technological differences are similar across countries, the Rajan and Zingales measure of external finance dependence can be used for different countries.

We use the aforementioned external finance measure for two additional reasons. ${ }^{7}$ Firstly, our analysis relies on the well-cited paper by Rajan and Zingales (1998). Secondly,

\footnotetext{
7 A number of studies in the literature employ the Rajan and Zingales measure of external finance owing to its exogeneity. These include the works of Gupta and Yuan (2003, 2009), Claessens and Laeven (2005), Guiso et al. (2004), Cetorelli (2001), and Cetorelli and Gambera (2001), among others.
} 
if we were to use country-specific measures of finance dependence for Europe, there would be an issue of endogeneity, because growth may be affected by external dependence. By using the US measure, external finance dependence becomes exogenous to the growth process of the various European countries.

\section{Interaction term}

Given our harmonization index and the external finance dependence measure of Rajan and Zingales (1998), we construct our interaction term to help identify the simultaneous effect of harmonization and external finance dependence on growth, as follows:

$$
\left(\text { Harmonization }_{i, t} \times \operatorname{exf}_{s}\right)_{i, s, t} \text {, }
$$

where $i$ denotes a country, $s$ denotes an industry, $t$ denotes time (years), ${ }^{8}$ Harmonization $_{i, t}$ is the harmonization index constructed using the FSAP directives, and $\operatorname{exf}$ is the industry-variant external finance dependence measure of Rajan and Zingales (1998).

With the interaction term that includes country, industry, and time variability, we account for the effects of harmonization in industries that require external financing on the growth rate.

\section{E. Other control variables}

In order to examine the relationship between financial harmonization and industrial growth thoroughly, we may need to control for a number of legal and institutional variables, as well as financial and stock market development indicators. The control variables described in detail below are country and time-variant, and cover the period $1996 \sim 2007^{9}$

\footnotetext{
${ }^{8}$ Similarly, as robustness checks, we construct two additional interaction terms that depend on the various harmonization indices, namely $\left(\text { Harmonization }_{i, t}^{*} \times \operatorname{exf}_{s}\right)_{i, s, t}$ and $\left(\text { Harmonization }_{i, t}^{* *} \times \operatorname{exf}_{s}\right)_{i, s, t}$.

${ }^{9}$ Owing to the lack of data at the industry, country, and time level, we choose to use country and time-variant controls in our estimations.
} 
We employ a series of legal and institutional variables from the World Bank's Worldwide Governance Indicators (1996 2009). We use different measures to control for institutional, legal, political, and economic factors that may affect the overall level of growth: government effectiveness, regulatory quality, and rule of law. These are constructed using subjective and perception-based data that reflect the views of a range of respondents, agencies, and organizations, and values range from -2.5 to 2.5 , where higher values correspond to better governance outcomes.

To measure financial development, we employ the ratio of deposit money bank assets to the sum of deposit money bank assets and central bank assets, from the Beck et al. (2000) Financial Development and Structure Database. This variable demonstrates the weight of deposit money bank assets to total assets, and indicates the importance of private lending. For stock market development, we use the stock market turnover ratio, from the same database. This variable is measured as the ratio of the value of total shares traded to stock market capitalization, and depicts the efficiency of stock market transactions.

Control variables help in further explaining the effect of harmonization on industrial growth. The timing of the implementation of the harmonization policies could be driven by the state of financial and stock market development in a country. The ease of adopting FSAP directives into national law can be induced by the quality of regulatory and legislative institutions. We include the above variables in order to control for these potential influences, verify the robustness of our benchmark model, analyze the possibility of extending our model to a dynamic case, and account for factors that may not be fully encountered in a fixed-effects setting.

\section{Empirical Specification}

Our analysis is based on a model that measures the effects of financial harmonization and external finance dependence on industrial growth. Here, we follow the literature, including Jayaratne and Strahan (1996, 1997), Strahan (2002), Morgan et al. (2004), and Kalemli-Ozcan et al. (2010, 2013), assuming that the effects of harmonization and external finance dependence will impact growth through the harmonization index and/

\footnotetext{
${ }^{10}$ The institutional quality variables used in our analysis do not fluctuate widely over time. As a result, we use the averages of two consecutive years to replace the missing data for these three legal/institutional variables.
} 
or through the interaction term. Our benchmark model controls for average differences across countries and time in harmonization policies, and across industries in external finance dependence. This allows us to analyze the influence of harmonization policies using the index measure and using the interaction term, separately.

We propose the following benchmark model to measure the effect of external finance dependence and financial harmonization on industrial growth across countries and over time:

$$
\begin{aligned}
\text { GVAGRO }_{i, s, t}=\lambda_{i}+\mu_{s}+\theta_{t} & +\varphi G V A_{i, s, t-1}+\beta_{1} \text { Harmonization }_{i, t} \\
& +\beta_{2}\left(\text { Harmonization }_{i, t} \times \operatorname{exf}_{s}\right)_{i, s, t}+v_{i, s, t}
\end{aligned}
$$

where the dependent variable in the above equation is gross value-added growth, $\lambda_{i}$ represents country fixed effects, $\mu_{s}$ represents industry fixed effects, $\theta_{t}$ represents time fixed effects, $G V A_{i, s, t-1}$ is the lagged logarithm of gross value-added in levels, Harmonization $_{i, t}$ is the index measure created from the FSAP directives, and the interaction term is the product of the financial harmonization index and the external finance dependence measure of Rajan and Zingales. ${ }^{11}$

In the above equation, our main focus is the coefficients of the harmonization index and the interaction term. We would expect to find positive and significant coefficients for both terms, which would imply a positive effect of financial harmonization and financial deepening (measured by external finance dependence) on gross value-added growth. We examine how much industries benefit in terms of growth resulting from the harmonization of the financial markets within the EU, given that these industries require external finance. Similarly to the work presented in Rajan and Zingales (1998), we can make predictions about within-country differences between industries, and across time using an interaction term that reveals time, country and industry specifics. According to Rajan and Zingales 1998, this method allows correction for country, industry, and time characteristics, and avoids any potential omitted variable bias in the model specification.

Although the studies of Jayaratne and Strahan (1996, 1997), Strahan (2002), and Kalemli-Ozcan et al. (2010) do not suggest using a dynamic model, other studies examine whether the results of the benchmark model correspond to those using

\footnotetext{
${ }^{11}$ The above model in levels with fixed effects is consistent when $\operatorname{cov}\left(G V A_{i s, t-1}, v_{i s, t-1}\right)=0$. This implies that the lag of gross value-added has no correlation with the lag of the error term. However, this does not suggest that the lagged growth rate is uncorrelated with the lagged error term; that is, $\operatorname{cov}\left(\Delta G V A_{i, s, t-1}, v_{i, s, t-1}\right) \neq 0$. This assumption is sufficient to guarantee the efficiency of our benchmark model.
} 
instruments in estimations. In our benchmark setting, there may also be concerns over the effect of the anticipation of financial harmonization policies. That is, countries may initiate the adoption harmonization measures in the hope of enhancing growth. In order to account for this possibility, we extend our analysis to include a dynamic specification. Using a dynamic setting, we can calculate the speed of the adjustment of the harmonization policies, and can account for the long-run effects of the variables in our model. The dynamic panel data model used in our analysis is specified as follows: ${ }^{12}$

$$
\begin{aligned}
& \Delta \text { GVAGRO }_{i, s, t}=\gamma \Delta \text { GVAGRO }_{i, s, t-1}+\Delta \tau_{t}+\alpha_{1} \Delta \text { Harmonization }_{i, t} \\
& +\alpha_{2}\left(\Delta \text { Harmonization }_{i, t} \times \Delta \operatorname{exf}_{s}\right)_{i, s, t}+\sum_{k=1}^{6} \rho_{k} \Delta \text { Controls }_{i, t, k}+\Delta u_{i, s, t},
\end{aligned}
$$

where $G V A G R O_{i, s, t}$ is the country, industry, and time-variant gross value-added growth, $\tau_{t}$ represents the time fixed effects, Harmonization ${ }_{i, t}$ is the harmonization index of the FSAP measures, the interaction term is the product of the harmonization index and the external finance dependence measure of Rajan and Zingales, and Controls ${ }_{i, t, k}$ are control variables for harmonization differences, financial and stock market development, and legal and institutional measures which are country and time-variant. As before, we would expect to find positive values for both $\alpha_{1}$ and $\alpha_{2}$.

The above model no longer has country- or industry-specific effects. The dynamic panel data model accounts for these individual effects. The Arellano-Bond dynamic panel data model calculates the first differences of all terms in order to exclude the Nickell bias that occurs when the lagged dependent variable is correlated with the error term. The moment conditions that stem from the above model require that:

$$
E\left[G V A G R O_{i, s, t-k} \Delta u_{i, s, t}\right]=0 \text { for } \forall k \geq 2 .
$$

With this condition, the lagged dependent variable of gross value-added growth is guaranteed to be uncorrelated with the first difference of the error term, even though the first difference of the dependent variable could be correlated with the first difference of the error term.

Using one lag of the dependent variable as a regressor, we allow gross value-added growth rates across European countries to partially adjust to their long-run equilibrium value within one year. The first differences in the dynamic data model remove country

\footnotetext{
${ }^{12}$ We include time dummies in our dynamic panel data model to account for possible trends. Time dummies are also used as IV-type instruments in the dynamic panel data model estimations.
} 
and industry-variant and time-invariant specific effects. Thus, the dynamic panel data model avoids any potential correlation of possible fixed effects with the right-hand side regressors. In the next section, we describe our main findings for both the benchmark and dynamic panel data models, in detail.

\section{Results}

First, we report our results for the 25 EU member countries for 1971 2007. In our regressions with the benchmark model, we use fixed-effects estimations, with country-, industry-, and time-specific effects. However, for the dynamic panel data model, we use the Arellano-Bond dynamic panel specification.

\section{A. Benchmark model}

The results from Table 1 show the effects of the harmonization index and the interaction term on gross value-added growth in a fixed-effects estimation, with country, industry, and time effects. We would expect to find a positive effect of financial harmonization and the interaction term on growth. Among others, the FSA (2003) and London Economics (2002) stated that, through the FSAP, European economies would achieve an increase in real Gross Domestic Product (GDP) of 1.1\% over a decade. However, Columns (1) (3) of Table 1, each using a different harmonization index, depending on the number of directives included, report negative coefficients for harmonization on gross value-added growth. ${ }^{13}$ This implies that, as countries adopt the directives of the FSAP, industrial growth is negatively affected directly by the process of financial harmonization. Although the negative impact is only statistically significant for the banking integration directives in Column (3), this finding clearly runs counter to our initial expectations. The aim of the FSAP is to create policies that will be implemented

\footnotetext{
${ }^{13}$ The $t$-statistics reported in the tables are based on country- and industry-specific (clustered) heteroskedasticity and autocorrelation. Country and industry clustering controls for the correlation in errors across countries within an industry, and across industries within a country, and provides standard errors that are robust to heteroskedasticity. Therefore, using clustering in a fixed-effects model offers consistent estimation of a panel, while controlling for endogeneity.
} 
by member countries to achieve an optimal single financial market. Nevertheless, the interaction terms, constructed from different financial harmonization indices, are found to be positive and significant. This implies that growth requires a dependence on external finance, in addition to the adoption of harmonization policies. The lagged values of gross value-added are shown to be negatively significant in all columns, complying with our initial expectations that European countries experience slower growth perspectives in upcoming years.

Table 1. Financial harmonization and industrial growth

\begin{tabular}{|c|c|c|c|}
\hline \multirow{2}{*}{ Variables } & \multicolumn{3}{|c|}{ GVAGRO } \\
\hline & (1) & (2) & (3) \\
\hline $\begin{array}{l}\text { Log of Gross Value Added } \\
\text { (Lagged) }\end{array}$ & $\begin{array}{c}-0.0129 * * * \\
(-5.029) \\
{[0.00256]}\end{array}$ & $\begin{array}{c}-0.0129 * * * \\
(-5.027) \\
{[0.00256]}\end{array}$ & $\begin{array}{c}-0.0128 * * * \\
(-4.976) \\
{[0.00258]}\end{array}$ \\
\hline Harmonization & $\begin{array}{c}-0.0105 \\
(-1.323) \\
{[0.00795]}\end{array}$ & & \\
\hline $\begin{array}{l}\text { Harmonization interaction } \\
(\text { Harmonization } \times \text { exf })\end{array}$ & $\begin{array}{c}0.0144^{*} \\
(1.804) \\
{[0.00799]}\end{array}$ & & \\
\hline $\begin{array}{l}\text { Harmonization }^{*} \\
\text { (21 directives) }^{*}\end{array}$ & & $\begin{array}{c}-0.0110 \\
(-1.371) \\
{[0.00805]}\end{array}$ & \\
\hline $\begin{array}{l}\text { Harmonization }{ }^{*} \text { interaction }^{*} \times \text { exf) } \\
\left(\text { Harmonization }^{*} \times \text { ext }\right.\end{array}$ & & $\begin{array}{c}0.0145^{*} \\
(1.784) \\
{[0.00812]}\end{array}$ & \\
\hline $\begin{array}{l}\text { Harmonization }^{* *} \\
\text { (7 directives) }\end{array}$ & & & $\begin{array}{c}-0.0250 * * * \\
(-2.628) \\
{[0.00950]}\end{array}$ \\
\hline $\begin{array}{l}\text { Harmonization }^{* *} \text { interaction }^{* *} \times \text { exf } \\
\text { (Harmonization }\end{array}$ & & & $\begin{array}{c}0.0225^{*} \\
(1.677) \\
{[0.0134]}\end{array}$ \\
\hline Observations & 17,380 & 17,380 & 17,380 \\
\hline$R$-squared & 0.098 & 0.098 & 0.098 \\
\hline Country fixed effects & Yes & Yes & Yes \\
\hline Industry fixed effects & Yes & Yes & Yes \\
\hline Time fixed effects & Yes & Yes & Yes \\
\hline
\end{tabular}


(Note) (i) The $t$-statistics are shown in parentheses $(* * * p<0.01, * * p<0.05, * p<0.1)$ and standard errors are shown in square brackets.

(ii) GVAGRO is calculated as follows: $G V A G R O=\log \left(g v a_{i, s, t}\right)-\log \left(g v a_{i, s, t-1}\right)$. Harmonization Hitt $=\ln (1$ $+\operatorname{lex}_{i, t}$ ), where lex $\mathrm{x}_{\mathrm{i}, \mathrm{t}}$ represents the sum of all 27 directives, taking the value 1 on and after the date the directive came into effect, per country, and zero otherwise. Harmonization ${ }_{i, t}^{*}=\ln \left(1+\operatorname{lexro}_{i, t}\right)$,

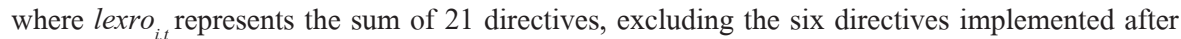
2003. Harmonization ${ }_{i, t}^{* *}=\ln \left(1+\right.$ banklex $\left._{i, t}\right)$, where banklex $_{i, t}$ represents the sum of all seven banking directives. exf is the external finance dependence of US firms in the 1970s, calculated by Rajan and Zingales (1998).

(iii) The estimation period in our regressions is 1971 2007. The above estimations include country, industry, and time effects not reported here. The $t$-statistics reported in the tables are based on country- and industry-specific (clustered) heteroskedasticity and autocorrelation.

Given that harmonization has a negative direct effect and a positive indirect effect (through the interaction term), we calculate the total effects of harmonization. This can be done by using the following partial derivative:

$$
\frac{\partial \text { GVAGRO }_{i, s, t}}{\text { Harmonization }_{i, t}}=\beta_{1}+\beta_{2} \operatorname{exf}_{s} .
$$

Since our primary concern is the impact of harmonization policies implemented through the FSAP, we observe total effects using the above equation. The calculations show that at the mean level of external finance dependence, the partial derivative of gross value-added growth across industries, with respect to the harmonization index, is equal to -0.0094 . At the minimum level of external finance dependence, the partial derivative takes on a value of -0.0148 , whereas at the maximum level of external finance dependence, the partial derivative is -0.0027 . The results imply that the overall effect of the harmonization policies on growth is negative. The positive interaction terms simply convey that the negative effect of the harmonization policies is somewhat mitigated in industries with higher external finance dependence. The coefficient of harmonization from Column (3) of the banking directives implies that growth across countries and industries has decreased by $2 \%$, since the implementation of the FSAP directives (exp $(-0.025)=0.9753)$.

Taken together, our results are puzzling. The negative effect of harmonization, particularly that of the banking directives on industrial growth, is difficult to explain, given the initial objectives of the FSAP. Our findings demonstrate that the effect of the FSAP directives on growth was not as beneficial as policymakers had initially expected. 
These findings could be due to different factors.

\section{Integration versus uniformity}

A first possibility is that the directives did not all serve to reduce costs through market integration. Harmonization is a broad term that could capture different realities. On the one hand, harmonization could refer to integration, thus lowering the cost of cross-border financial activity. On the other hand, harmonization could simply mean uniformity, without necessarily implying the lowering of costs. Therefore, we classify the directives into three groups: those that imply integration, those that imply uniformity, and the remainder. The first category of directives, those that promote integration, is made up of directives that aim to improve the efficiency of payments, eliminate tax distortions, simplify regulation, create a single passport for securities, increase competition, remove barriers and restrictions, expand investment options, and reduce the cost of capital. The main goal of this category is to lower the costs of cross-border financial activity. The second category of directives, those that promote uniformity, seeks to improve risk management, harmonize cross-border supervision, encourage innovation, improve prudential regulation and rules, and increase consumer confidence and protection. Although these directives may also contribute to removing some restrictions, they are aimed more towards making rules and regulation more uniform, and often involve increasing the costs of cross-border financial activity. ${ }^{14}$ The third category consists of all other directives that are not easily classifiable under the first two categories.

Columns (1) (3) of Table 2 report the same specification as Table 1, but employ a different harmonization index for each of the three categories of directives. Using the same indexing strategy discussed earlier, the findings demonstrate that the uniformity index has a negative impact on industrial growth. Both integration and the others indices are non-significant. This result shows that not all harmonization is the same: harmonization that effectively improves market integration ceases to have a significant negative impact, whereas harmonization aimed mainly at making countries "similar" continues to have a negative effect on growth. Accounting for the interaction term reinforces this dichotomy, as it is found to be positively significant for those directives that promote integration, but non-significant for those directives that promote uniformity

\footnotetext{
${ }^{14}$ Increasing costs refers mostly to the cost of compliance and capital costs, which are borne by investors and issuers across countries.

${ }^{15}$ Note that the classification of the directives under each category can be regarded as being subjective. However, the main goal of this analysis is to examine whether the effect of financial harmonization on industrial growth is amplified when directives with similar objectives are grouped.
} 
for industries with a higher dependence on external funds. Taken together, this suggests that harmonization, when thought of as integration, has an overall positive effect, ${ }^{16}$ whereas harmonization as uniformity has an overall negative effect on industrial growth. More broadly speaking, some directives may lower the cost of cross-border financial activity, whereas others may increase it. Thus, grouping all the directives under the common term of "harmonization" may be misleading.

${ }^{16}$ The positive effect of the integration directives holds for industries that have a higher dependence (at the maximum level) on external finance. In other words, at the maximum level of external finance dependence, harmonization that implies integration has a positive impact on industrial growth. 


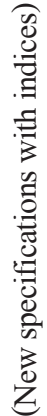

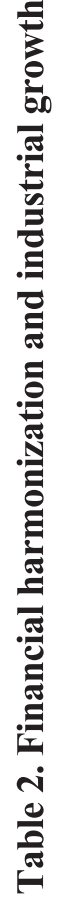

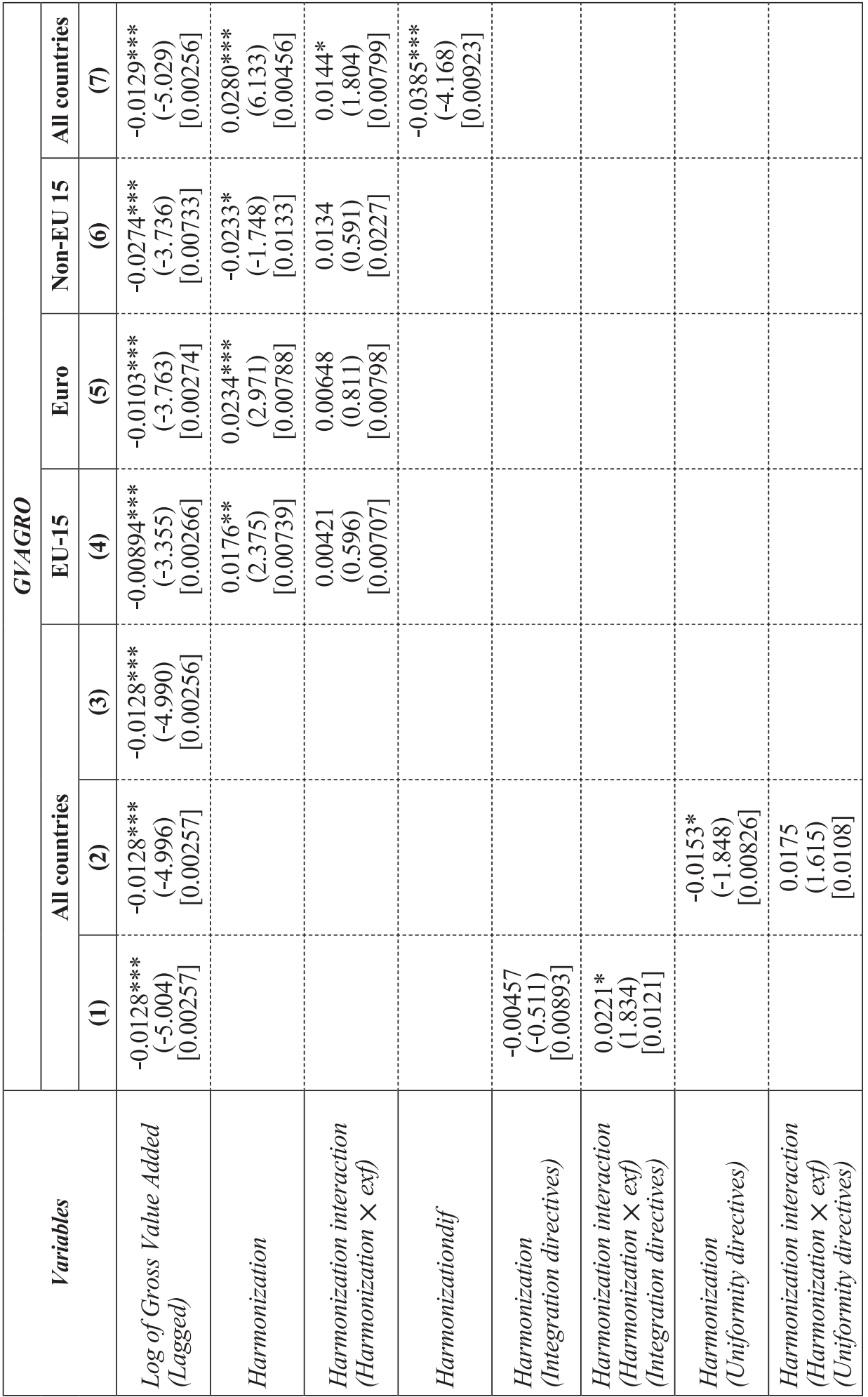


侸

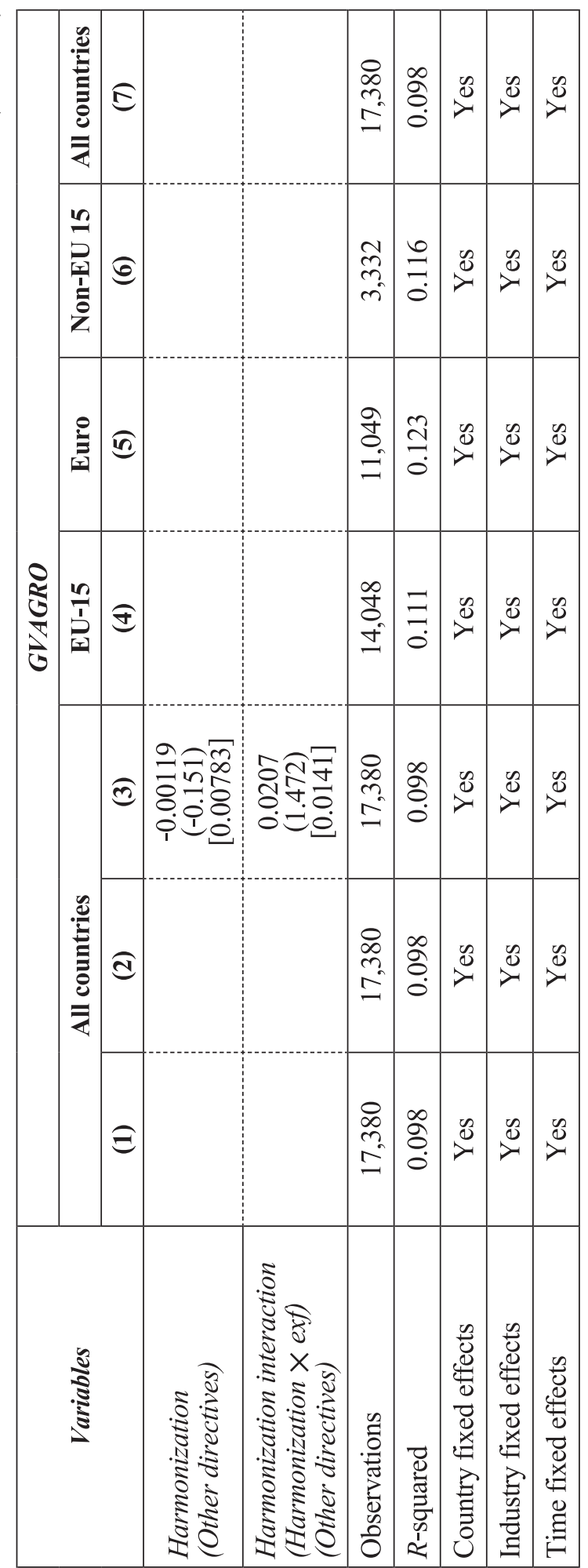

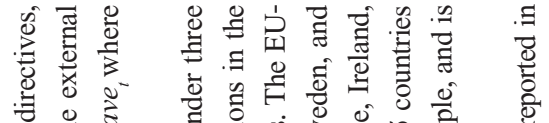

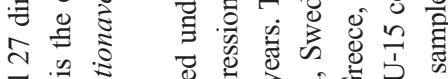

需

茨

छ.

क

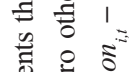

它

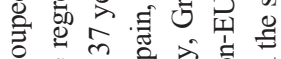

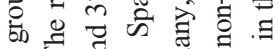

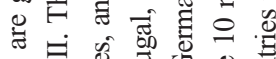

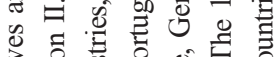

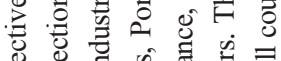

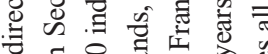

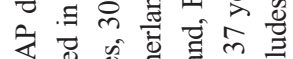

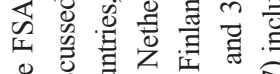

ङ

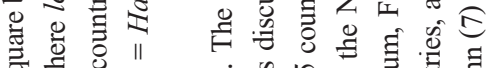

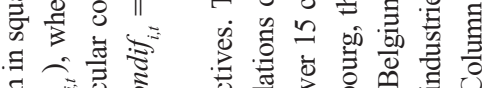

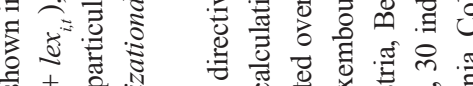

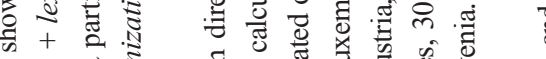

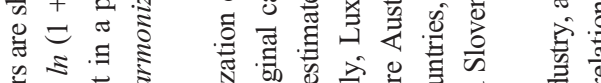

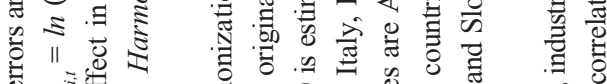

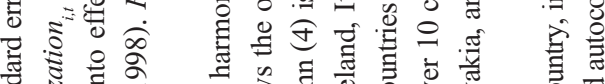

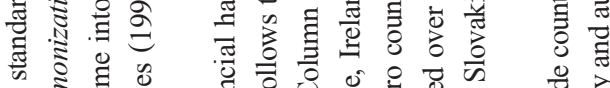

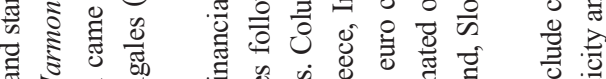

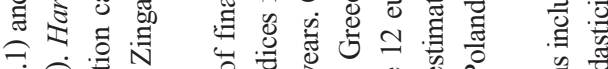

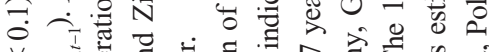

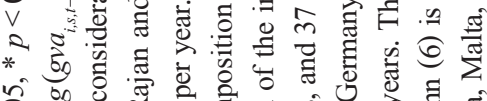

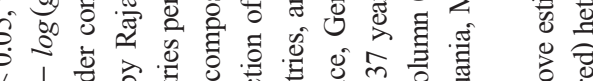

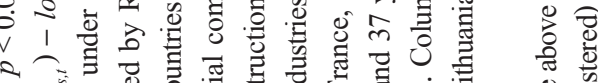
२)

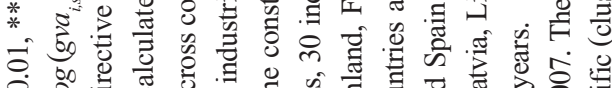
○. २ II

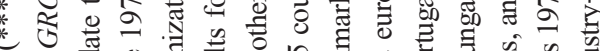

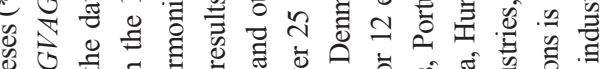

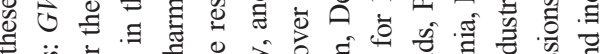

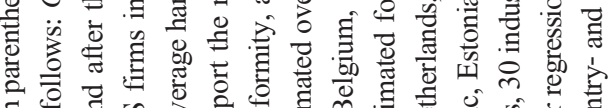

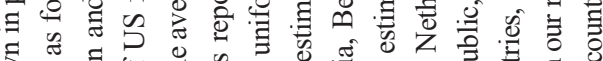
空要

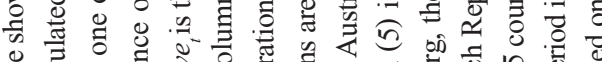

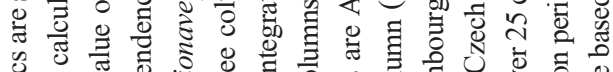

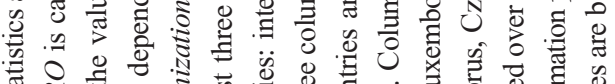

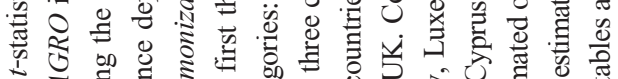

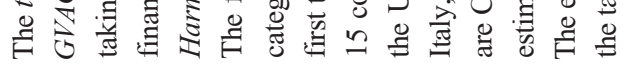
$\fallingdotseq \ominus$ 目 로 


\section{EU-15 versus the rest}

A second possibility for the negative effect of harmonization in our benchmark specification is the behavior that new member states of the EU could exhibit that differs from that of the original EU-15 members. This difference may not be adequately picked up by the country-fixed effects. Alexander (2002) notes that one of the biggest criticisms of the FSAP measures is that they have been implemented without further consideration of the structural basis of integration in securities, retail, and financial markets across the EU. This suggests that the FSAP measures may not be as effective in markets that are not completely integrated. Truly integrated markets should benefit from financial harmonization through the reduction in costs of investment, enhancements in consumer protection, improvements in the allocation of investment resources, and innovation. However, without a well-integrated financial market, financial harmonization policies could only provide small benefits to EU member countries.

Therefore, we believe that the EU-15 countries, which have been a part of the union for far longer, may differ from the newer members of the EU in terms of their response to the implementation of the FSAP policies. Similarly, being part of a monetary union might have an additional influence on growth. Another issue is that the FSAP was largely negotiated when the new member states were not yet a part of the EU, raising the possibility that their specific needs were not sufficiently taken into account. If so, we would expect financial harmonization to have a positive impact on the growth rate of EU-15 countries, unlike the negative effect found for the entire sample.

In order to analyze this issue further, we divide our sample set into subgroups. In Column (4) of Table 2, we report the results for the EU-15 countries. Column (4) shows that the harmonization index is in fact positively significant. This implies that, for EU15 countries, financial harmonization has a positive impact on industrial growth. In Column (5) we examine the case with Euro countries. In the Euro countries, the effects of financial harmonization should be enhanced, owing to the existence of a monetary union. Consistent with this view, in Column (5), we find that the harmonization index is not only positive, but also very significant. Lastly, Column (6) shows that the effect of financial harmonization is negative for the non-EU-15 countries. The interaction terms are positive, but non-significant in all regressions reported in Columns (4) (6). Overall, this suggests that the Euro and the EU-15 countries benefited most, whereas the new member states seem to have suffered a negative effect from the FSAP. ${ }^{17}$

\footnotetext{
${ }^{17}$ We have also accounted for the influence of the euro industrial growth rates by including a euro dummy in our estimations. The
} 


\section{Relative timing (speed) of adoption}

A third possibility for our initial finding of a negative effect of harmonization on growth might be related to the relative timing of adoption. For example, if Czech Republic adopts a directive, and no other country adopts the same directive, then we cannot talk about harmonization. In that case Czech Republic would simply bear the cost of adopting the directive, without attaining any benefits from it. Not controlling for this would introduce a bias. Given that there exist significant differences across EU member countries in terms of when they adopted the directives, this is a potential issue. Recall that the FSAP directives need to be transposed into national law before they become effective. This has to be done within a specified period, but some countries do so sooner than others do.

With this in mind, we consider whether there is a disadvantage from adopting these directives early. In order to check for this possibility, we construct a new variable, which we call the harmonization difference:

$$
\text { Harmonizationdif }_{i, t}=\text { Harmonization }_{i, t}-\text { Harmonizationave }_{t} \text {, }
$$

where Harmonization $_{i, t}$ is the harmonization index of country $i$ in year $t$, and Harmonizationave $_{t}$ is the average index of harmonization across countries in year $t$. The harmonization difference is a measure of how many FSAP directives are adopted by each country, relative to the average rate of adoption for all countries per year. Using this variable we can analyze the impact on industrial growth of being an early versus a late adopter. Column (7) of Table 2 reports the results when this new variable is included in our full sample. As expected, our findings show that there is a negative effect of being an early adopter. Thus, even though the FSAP directives aim to unify financial markets across the EU, this will only be mutually beneficial for countries when they all implement these directives.

More importantly, once we control for the harmonization difference, the harmonization index is now positive and significant. The positive effect of harmonization is carried through both the harmonization index and the interaction term, which implies that the growing need for external finance, together with the ongoing process of transposition of the directives, enhances industrial growth. With the inclusion of the harmonization difference measure, the harmonization index acts as an average harmonization indicator 
that generates the impact of harmonization across countries, at the average level.

Table 3 presents our findings for three different samples. Column (1) reports the results for EU-15 countries. The harmonization index is found to be positively significant, implying that the adoption of the FSAP directives by EU-15 countries augments growth. The coefficient of the harmonization difference measure is negative, but not significant, indicating that being an early adopter does not have a clear negative effect on industrial growth. Similarly, the harmonization index is found to be positive and significant, and the harmonization difference measure is negative and non-significant for Euro countries in Column (2). The interaction terms in both columns demonstrate that, for EU-15 and Euro countries, the effects of harmonization are not stronger in industries that depend more on external finance. ${ }^{18}$ Column (3) depicts the results for non-EU 15 countries. Here, the harmonization index is no longer significant, whereas the harmonization difference is negatively significant, suggesting that among the non-EU 15 countries, it is clearly more beneficial to be a late adopter than an early one.

Taken together, our results imply that, once we control for the relative timing of adoption, harmonization has a positive effect on growth, though that effect is not always statistically significant. The sign of the harmonization index changes, conditional on the inclusion of the harmonization difference measure that accounts for the relative timing of adoption. As for being an early adopter, our results show that this is true for all cases, but only statistically significant for the non-EU 15 countries and for the entire sample.

\footnotetext{
${ }^{18}$ At the mean level of external finance dependence across industries, the overall effect of harmonization for EU-15 and Euro countries is positive. The overall effect for non-EU 15 countries at the mean level of external finance is negative, implying that the overall impact of harmonization on industrial growth is not beneficial.
} 


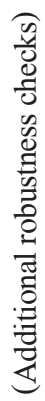

\begin{tabular}{|c|c|c|c|c|c|c|c|c|c|c|}
\hline 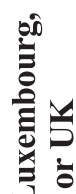 & $\mathbb{E}$ & 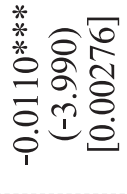 & 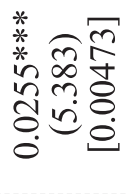 & 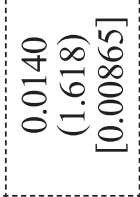 & 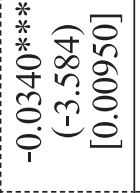 & $\frac{\infty}{n}$ & $\stackrel{\overrightarrow{0}}{\stackrel{0}{0}}$ & $\stackrel{0}{\infty}$ & $\stackrel{\theta}{\nu}$ & $\stackrel{\infty}{\infty}$ \\
\hline 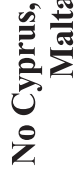 & (2) & 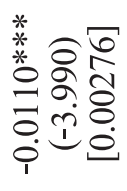 & 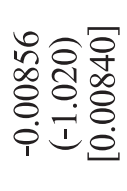 & 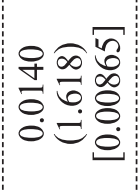 & & $\frac{\infty}{n}$ & $\begin{array}{l}0 \\
0 \\
0\end{array}$ & $\stackrel{0}{\nu}$ & $\stackrel{0}{\nu}$ & $\stackrel{\infty}{\infty}$ \\
\hline 冚 & $\sqrt{2}$ & 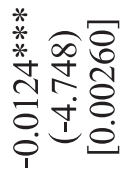 & 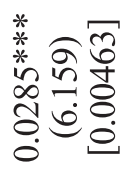 & 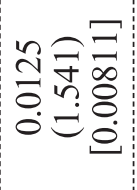 & 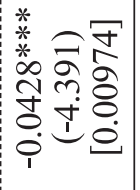 & $\begin{array}{l}\frac{1}{7} \\
\underset{6}{0}\end{array}$ & $\begin{array}{l}\infty \\
\stackrel{0}{0} \\
0\end{array}$ & $\stackrel{0}{0}$ & $\stackrel{0}{\infty}$ & $\stackrel{0}{\infty}$ \\
\hline 疍 & f & 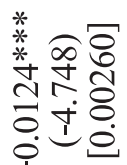 & 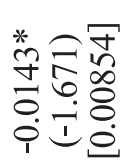 & 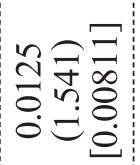 & & $\begin{array}{l}\stackrel{n}{t} \\
\underset{6}{0}\end{array}$ & $\begin{array}{l}\infty \\
\stackrel{0}{0} \\
0\end{array}$ & $\underset{\nu}{\infty}$ & $\stackrel{0}{\nu}$ & $\stackrel{\infty}{\infty}$ \\
\hline
\end{tabular}

है

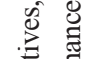

进

글

흐

낭

声

$\rightleftarrows$

营

这密

要通

들

焉离令

$\Xi 20$

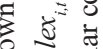

क

$\stackrel{\square}{=}$

$\approx \frac{0}{0}$

$=\Xi$

要 密

预

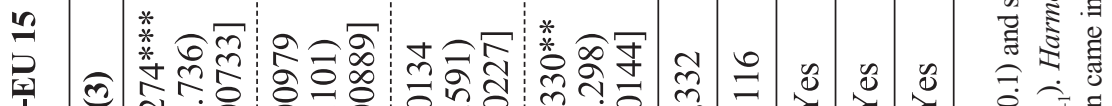

•

\&

28

* है क्षे

0 .

$v$
2

*

के छु.

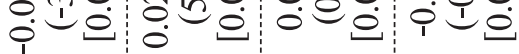

₹ 11 :

*

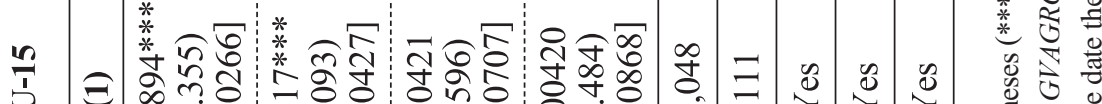

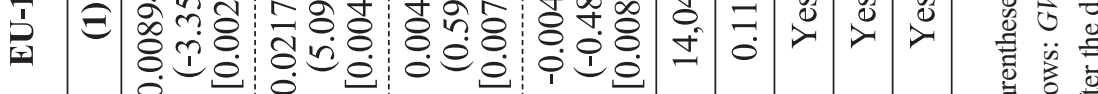

总, 范

$\Xi \underset{\text { व }}{\square}$

हैं

के

जै है

.

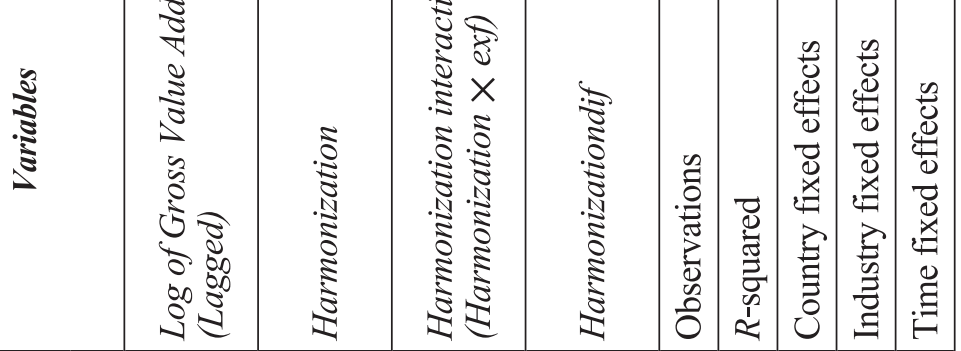

용

ए

낭

$Ð \ni$

¿ี 
dependence of US firms in the 1970s, calculated by Rajan and Zingales (1998). Harmonizationdif $f_{i, t}=$ Harmonization $_{i, t}-$ Harmonizationave $_{t}$ where Harmonizationave ${ }_{t}$ is the average harmonization across countries per year.

(iii) Column (1) is estimated over 15 countries, 30 industries, and 37 years. The EU-15 countries are Austria, Belgium, Denmark, Finland, France, Germany, Greece, Ireland, Italy, Luxembourg, the Netherlands, Portugal, Spain, Sweden and the UK. Column (2) is estimated over 12 euro countries, 30 industries, and 37 years. The 12 euro countries are Austria, Belgium, Finland, France, Germany, Greece, Ireland, Italy, Luxembourg, the Netherlands, Portugal, and Spain. Column (3) is estimated over 10 countries, 30 industries, and 37 years. The 10 non-EU-15 countries included are Cyprus, Czech Republic, Estonia, Hungary, Latvia, Lithuania, Malta, Poland, Slovakia, and Slovenia. Columns (4) and (5) are estimated over 23 countries, 30 industries, and 37 years, and exclude Latvia and Poland. Finally, columns (6) and (7) are estimated over 21 countries, 30 industries, and 37 years, and exclude Cyprus, Luxembourg, Malta, and the UK.

(iv) The estimation period in our regressions is 1971 2007. The above estimations include country, industry, and time effects not reported here. The $t$-statistics reported in the tables are based on country- and industry-specific (clustered) heteroskedasticity and autocorrelation.

\section{Exclusion of some countries}

A fourth possibility for our initial finding might be the result of a bias introduced by the inclusion of certain countries in our sample. Analyzing the countries in further detail, Latvia and Poland seem to have adopted some FSAP directives much earlier than did other non-EU 15 countries. In fact, the data from the European Commission suggest that they adopted some of these measures before becoming part of the EU. This could potentially be the result of amendments to existing directives that had already been transposed into domestic law prior to the implementation of the FSAP. In order to verify whether these two countries create any bias for the effect of harmonization on industrial growth, we exclude them from our sample and reanalyze our benchmark model. The results in Column (4) and Column (5) of Table 3 are similar to those reported in Table 1 and Table 2. The harmonization index is found to be negatively significant when we exclude Latvia and Poland from our sample. Once again, the inclusion of the harmonization difference measure causes the harmonization index to become positively significant, indicating that harmonization is beneficial for growth, but that being an early adopter is not.

We also examine the sensitivity of our results by excluding four countries that might cause potential bias owing to their large share of foreign banks and liabilities. In order to test whether the effects of external finance dependence of industries and the enhancement of harmonization policies on industrial growth are triggered by including countries with greater banking shares, we exclude Cyprus, Malta, Luxembourg, and the UK from our 
estimations. Column (6) shows non-significant effects for the harmonization index and the interaction term. In Column (7), the harmonization index is found to be positively significant, and the harmonization difference measure negatively and significant, which corresponds to the results in Column (7) of Table 2. This suggests that the exclusion of countries with a larger share of foreign banks and liabilities does not alter our main findings.

\section{Competing explanations}

So far, we have given four possible reasons for a negative relationship between financial harmonization, following the FSAP policies, and the industrial growth rates across European countries. A negative relationship could occur as a result of harmonization capturing different realities, such as integration and uniformity, the FSAP policies aiming to create benefits for those that have been a part of the EU for a longer period, the likely impact of some countries with larger banking shares, which may potentially bias the results, or the difference in the timing of adoption of the FSAP directives. We have shown that EU-15 and Euro countries have a positive coefficient for financial harmonization. Similarly, the exclusion of countries that have larger banking shares does not alter our initial finding of a negative result. Thus, the two remaining reasons for the initial negative effect of harmonization on growth are the nature of harmonization, and its timing. In order to study which of these competing explanations is dominant, we test our results using indices for integration, uniformity, and other directives, taking into account the relative timing of the adoption of the FSAP directives in our regressions. The results reported in Table 4 show that with the inclusion of the relative timing of adoption, financial harmonization becomes positively significant. The findings reveal that the negative effect is the result of not accounting for the speed of adoption.

\footnotetext{
${ }^{19}$ Further robustness checks using integration, uniformity, and other directives with control variables strengthen the argument that the relative timing of adoption is the dominant factor behind the initial negative effect of financial harmonization on industrial growth.
} 


\section{Table 4. Financial harmonization and industrial growth}

(Competing explanations)

\begin{tabular}{|c|c|c|c|}
\hline \multirow{2}{*}{ Variables } & \multicolumn{3}{|c|}{ GVAGRO } \\
\hline & (1) & (2) & (3) \\
\hline $\begin{array}{l}\text { Log of Gross value added } \\
\text { (Lagged) }\end{array}$ & $\begin{array}{c}-0.0128 * * * \\
(-5.004) \\
{[0.00257}\end{array}$ & $\begin{array}{c}-0.0128 * * * \\
(-4.996) \\
{[0.00257]}\end{array}$ & $\begin{array}{c}-0.0128 * * * \\
(-4.990) \\
{[0.00256]}\end{array}$ \\
\hline $\begin{array}{l}\text { Harmonization } \\
\text { (Integration directives) }\end{array}$ & $\begin{array}{c}0.0368 * * * \\
(6.029) \\
{[0.00611]}\end{array}$ & & \\
\hline $\begin{array}{l}\text { Harmonization interaction } \\
\text { (Harmonization } \times \text { exf) } \\
\text { (Integration directives) }\end{array}$ & $\begin{array}{l}0.0221 * \\
(1.834) \\
{[0.0121]}\end{array}$ & & \\
\hline $\begin{array}{l}\text { Harmonizationdif } \\
\text { (Integration directives) }\end{array}$ & $\begin{array}{c}-0.0414 * * * \\
(-3.804) \\
{[0.0109]}\end{array}$ & & \\
\hline $\begin{array}{l}\text { Harmonization } \\
\text { (Uniformity Directives) }\end{array}$ & & $\begin{array}{c}0.0409 * * * \\
(6.196) \\
{[0.00660]}\end{array}$ & \\
\hline $\begin{array}{l}\text { Harmonization interaction } \\
(\text { Harmonization } \times \text { exf) } \\
\text { (Uniformity directives) }\end{array}$ & & $\begin{array}{l}0.0175 \\
(1.615) \\
{[0.0108]}\end{array}$ & \\
\hline $\begin{array}{l}\text { Harmonizationdif } \\
\text { (Uniformity directives) }\end{array}$ & & $\begin{array}{c}-0.0562 * * * \\
(-5.148) \\
{[0.0109]}\end{array}$ & \\
\hline $\begin{array}{l}\text { Harmonization } \\
\text { (Other directives) }\end{array}$ & & & $\begin{array}{c}0.0488 * * * \\
(6.569) \\
{[0.00743]}\end{array}$ \\
\hline $\begin{array}{l}\text { Harmonization interaction } \\
\text { (Harmonization } \times \text { exf) } \\
\text { (Other directives) }\end{array}$ & & & $\begin{array}{l}0.0207 \\
(1.472) \\
{[0.0141]}\end{array}$ \\
\hline $\begin{array}{l}\text { Harmonizationdif } \\
\text { (Other directives) }\end{array}$ & & & $\begin{array}{c}-0.0500 * * * \\
(-4.399) \\
{[0.0114]}\end{array}$ \\
\hline Observations & 17,380 & 17,380 & 17,380 \\
\hline$R$-squared & 0.098 & 0.098 & 0.098 \\
\hline
\end{tabular}

(Note) (i) The $t$-statistics are shown in parentheses $(* * * p<0.01, * * p<0.05, * p<0.1)$ and standard errors are shown in square brackets.

(ii) GVAGRO is calculated as follows: $G V A G R O=\log \left(g v a_{i, s, t}\right)-\log \left(g v a_{i, s, t-1}\right)$. Harmonization Hitt $=\ln (1$ + lex $_{i, t}$ ), where $l e x_{i, t}$ represents the sum of all 27 directives, taking the value one on and after the date the directive under consideration came into effect in a particular country, and zero otherwise. exf is the external finance dependence of US firms in the 1970s, calculated by Rajan and Zingales (1998). 
Harmonizationdif $_{i, t}=$ Harmonization $_{i, t}-$ Harmonizationave $_{t}$ where Harmonizationave ${ }_{t}$ is the average harmonization across countries per year. The first three columns report the results for an industrial composition of financial harmonization directives. The FSAP directives are grouped under three categories: integration, uniformity, and others. The construction of the indices follows the original calculations discussed in Section II. The above estimations include the lagged logarithm of gross value-added in levels. The regressions in the first three columns are estimated over 25 countries, 30 industries, and 37 years.

(iii) The estimation period in our regressions is 1971 2007. The above estimations include country, industry, and time effects not reported here. The $t$-statistics reported in the tables are based on country- and industry-specific (clustered) heteroskedasticity and autocorrelation.

The findings from Table 2, Table 3, and Table 4, as well as the harmonization difference, show that being an early adopter could lead to lower growth in all 25 countries, and in different subgroups of countries. In order to correctly examine the impact of early versus late adoption, we need to include additional controls in the model.

\section{Additional controls}

Adding further controls may be important in order to avoid an omitted variable bias. Given the difficulty in finding control variables at the industrial level with country and time variation, we focus on controls that are country and time variant, and include country, industry, and time fixed effects to account for all other influences. First, in order to account for the structural features of the banking systems in European countries, we follow the methodology proposed by Kalemli-Ozcan et al. (2010), using control variables for banks' overhead costs, banks' profitability, and banking concentration, taken from the Beck et al. (2000) Financial Development and Structure Database (2000). Given that there exist concerns over the implementation of the FSAP and its dependence on local banking system conditions, we believe that the inclusion of these variables can provide a better picture of the link between harmonization policies and industrial growth. The results, not reported here, have no systematic effects on our model. Second, in order to account for differences in legal, institutional, and governmental structures, as well as in stock market and overall financial development, we include country- and time-variant measures in our model.

Appendix 1 reports the results for the overall sample, EU-15 countries, and non-EU 15 countries when control variables for financial and stock market development and legal and institutional quality are included. The short period of the availability of financial development indicators and legal variables reduces our sample size to the period 1996 2007. Column (1), Column (3), and Column (5) show that, when not controlling 
for the harmonization difference measure, the harmonization index is negative and significant for all countries and for non-EU 15 countries, and positive and non-significant for EU-15 countries. The inclusion of the harmonization difference measure in Column (2), Column (4), and Column (6) leads to a change in the signs of the harmonization indices. $^{20}$ The coefficients of the interaction terms imply that the simultaneous effect of harmonization and external finance dependence is negative on industrial growth. Overall, the results show that harmonization is beneficial for all countries, conditional on the relative timing of adoption, and with the inclusion of further controls that account for outside effects. However, being an early adopter of the FSAP directives proves to have a disadvantageous effect on growth. This is now true for all groups of countries, though the effect is non-significant for the EU-15 subgroup.

\section{Legal origins}

Lastly, we consider whether the results of our benchmark model alter with the inclusion of legal origins of countries. Legal origins refer to the differences across countries in terms of their legal systems, which are structured according to families of law. As La Porta et al. $(1997,1998,2008)$ present in their series of articles, the most popular legal traditions are the common law and the civil law, from which several subtraditions such as the French, German, socialist, and Scandinavian legal origins arise. However, for our particular study, there is little difference between the French, German, and British laws that implement the EU legislation proposed under the FSAP. However, the way in which these provisions will be included into domestic law, and the manner in which the directives will be monitored and enforced may show vast differences across member countries. Our analysis with the addition of legal origins finds the effect of the financial harmonization index to be negative but non-significant on industrial growth for all countries. ${ }^{21}$ Once again, the signs of harmonization indices across all countries, EU-15 countries, and non-EU-15 countries change when the harmonization difference measure is included in the model. Although the legal origin dummies for the UK, France, Germany, socialist regimes, and Scandinavian countries appear to be significant in some regressions, the results obtained are similar to those from the benchmark case, and to those shown in Table 3.

\footnotetext{
${ }^{20}$ The change in the sign occurs for all countries and for non-EU-15 countries.

${ }^{21}$ The results are available upon request from the author.
} 


\section{B. Dynamic panel data model}

We include a dynamic panel data model to examine the partial adjustment property of harmonization policies, analyze the possible long-run effects of harmonization, and determine whether a dynamic setting would add to the relationship between harmonization and growth. There are two important points to note with regard to causality in a dynamic setting. First, even if governments of countries in the EU anticipate higher growth rates following harmonization, it is unlikely that the officials in each industry could determine the timing of adoption in their own country and in other countries. ${ }^{22}$ Secondly, and more importantly, if countries harmonize because of expected growth, early harmonization should be beneficial. In fact, we find the opposite, which we report in the following section.

Appendix 2 shows the results of four different dynamic Arellano-Bond GMM-type panel models. Owing to the use of control variables, the estimation period is reduced to 1996 2007. The lagged dependent variable in Column (1) has a negative and significant coefficient. The harmonization index in the dynamic panel data model is found to have a positively significant effect when the harmonization difference measure and other control variables are included in the model. The harmonization difference measure is found to be negative and significant. Column (2) and Column (3) report the results for EU-15 countries, and Column (4) and Column (5) report the results for non-EU-15 countries. In Column (2), the lagged dependent variable is negative and significant, implying that previous growth perspectives lead to a slowdown in current growth. However, the variables of interest are found to have non-significant coefficients. ${ }^{23}$ Column (4) shows that for non-EU-15 countries, none of the variables of interest are statistically significant. In order to correct for this problem, in Column (5), we report the results for non-EU-15 countries with controls using additional instruments. ${ }^{24}$ Then, the harmonization index

\footnotetext{
${ }^{22}$ Both Rajan and Zingales (1998) and Klenow (1998) argue that there is low correlation across industrial growth rates. This low correlation in industrial growth stands as an additional reason explaining why causality (or the endogeneity of harmonization) is not a problem in our analysis.

${ }^{23}$ Column (3) uses government effectiveness and the deposit money bank assets-to-central bank assets ratio as additional instruments. The inclusion of these variables as instruments does not change our estimations significantly.

${ }^{24}$ The instruments used in the dynamic panel data model estimations fall under two categories: GMM- and IV-type instruments. GMM-type instruments consist of endogenous variables such as the lagged dependent or explanatory variables. IV-type instruments are explanatory variables that are exogenous and an additional set of instruments that are not part of the original equation. All columns use the 4th lag of the logarithm of gross value-added in levels as GMM-type instruments. However, Column (1), Column (2), and Column (3) use the political stability measure taken from the Worldwide Governance Indicators data set, lag of the harmonization index, lag of the interaction term, and time dummies as IV-type instruments. In addition to these, Column (4) uses the ratio of deposit money bank assets to the sum of deposit money bank and central bank assets, stock market turnover ratio, and government effectiveness as instruments. We use political stability as an instrument owing to its exogeneity with industrial growth. Our estimations including this variable as a control do not
} 
is found to be positive and significant. The harmonization difference is also negatively significant, implying that being an early adopter for non-EU-15 countries is not beneficial. In all estimations, the Arellano-Bond tests of serial correlation show that we do not have any problems concerning the error terms in our regressions. In addition, the Sargan tests do not report over-identification problems with regard to the instruments used in the estimation of the model, in all columns. Experimenting with different control variables that are common to growth regressions, such as the secondary school enrollment rate, and government or health expenditure, does not alter the results reported by the dynamic panel data model.

To analyze the long-run effects of the harmonization policies and the interaction term, we divide each coefficient by $1-\gamma$, where $\gamma$ represents the coefficient of the lagged dependent variable in our model. The results show that the harmonization index has a positive coefficient for growth when we consider its long-run impact. ${ }^{25}$ This suggests that, given the shorter sample, and the control variables selected, the effect of harmonization will be positive in the long run. The interaction term has a negative effect on growth, implying that in the long run, the benefits of harmonizing in a full sample of European economies may not work through the simultaneous effect of industries' external dependence on finance. Nevertheless, the results of interest confirm our findings from the benchmark model, showing that harmonization has a positive effect on growth, once we consider the harmonization difference measure and other controls.

\section{Concluding Remarks}

Starting with the adoption of the euro in 1999, the EU has implemented initiatives to build a more integrated and harmonized financial market among its member states. With the establishment of the FSAP, the European Commission has taken a further step to integrate the European countries through legislative and regulatory terms in the banking, insurance, and securities markets.

\footnotetext{
show significant results, which strengthens our argument for using it as an instrument.

${ }^{25}$ The EU-15 countries have a negative coefficient for harmonization that is non-significant in Column (3), and a positive but nonsignificant coefficient in Column (4). We believe this change may be a result of the instruments selected in the analysis. Given that the coefficients are non-significant in either case, we refrain from concluding that the long-run impact of harmonization in EU-15 countries is either negative or positive.
} 
Since the goal of the FSAP is to enhance growth in Europe, this study assessed whether this has been the case. When using a standard specification, regressing growth on harmonization, while controlling for country, industry and time fixed effects, we find that harmonization did not have the expected effect. Instead, growth seems to have been negatively impacted by the introduction of the FSAP. However, this standard specification, used in other papers on financial deregulation and harmonization, fails to control for an important factor, namely the relative timing of adoption. Indeed, we would only expect harmonization to be beneficial if all countries adopt the directives. That is, having only some countries adopt the directives would not imply true harmonization, putting early adopters at a disadvantage. Once we control for the relative timing of adoption, we find that harmonization has the expected positive effect on growth, but that being an early adopter (mostly) has a negative effect. These results are robust to including different controls, splitting the sample into subgroups of countries, and extending the model to a dynamic specification.

Our results suggest several promising areas of future research. First, over time, as more data become available for a longer period, a more in-depth dynamic analysis of the impact of the FSAP can be carried out. Of particular interest would be to see whether the different behavior of the non-EU-15 countries, ${ }^{26}$ described in this paper, is mitigated over time. Second, our study has gone beyond the simple cross-country analysis common to many studies, by including industrial data. A natural next step would be to use firmlevel data. Doing so would enable a better measure of interaction between the impact of the FSAP and the dependence on external finance, at the firm level. Similarly, as more industrial data become available, the analysis could be extended to include the postcrisis period, as well as exploring the effect of business cycles in the adoption of the FSAP directives. ${ }^{27}$ Third, our findings show that the relative timing of adoption is key to understanding the impact of harmonization policies on growth. This suggests that controlling for this relative timing would benefit other studies that analyze the impact of deregulation or harmonization.

Received 19 January 2017, Revised 7 April 2017, Accepted 28 April 2017

\footnotetext{
${ }^{26}$ Another topic of interest is to uncover the channels that affect the EU-15 countries, and to explain their different behavior in some of our estimations.

${ }^{27}$ We would like to thank the anonymous referee for pointing out this possibility.
} 


\section{References}

Alexander, Kern. "Establishing a European Securities Regulator: Is the European Union an Optimal Economic Area for a Single Securities Regulator?" Cambridge Endowment for Research in Finance Working Paper No. 7 (2002): 1-41.

Arellano, Manuel, and Stephen Bond. "Some Tests of Specification for Panel Data: Monte Carlo Evidence and an Application to Employment Equations." Review of Economic Studies. 58(2) (1991): 277-97.

Beck, Thorsten, Asli Demirguc - Kunt, and Ross Levine. "A New Database on Financial Development and Structure.” World Bank Economic Review 14(3) (2000): 597-605.

Boyfield, Keith, Hugo Robinson, and Lorraine Mullally. Selling the City Short? A Review of the EU's Financial Services Action Plan. London: Open Europe in association with Keith Boyfield Associates, 2006.

Cetorelli, Nicola. "Does Bank Concentration Lead to Concentration in Industrial Sectors?" Federal Reserve Bank of Chicago Working Paper 2001-01 (2001):1-29.

Cetorelli, Nicola, and Michele Gambera. "Banking Market Structure, Financial Dependence and Growth: International Evidence from Industry Data." The Journal of Finance 56 (2) (2001): 617-48.

Claessens, Stijn, and Luc Laeven. "Financial Dependence, Banking Sector Competition, and Economic Growth." Journal of the European Economic Association 3 (1) (2005): 179-207.

De Avila, Diego Romero. "Finance and Growth in the EU: New Evidence from the Liberalisation and Harmonisation of the Banking Industry." European Central Bank Working Paper 266 (2003): 1-52.

European Commission. "FSAP Evaluation, Part I: Process and implementation." Financial Services Policy and Financial Markets Report (2005) Accessed April 19, 2017. http:// ec.europa.eu/internal_market/finances/docs/actionplan/index/070124_part1_en.pdf

FSA. "Completing the Financial Services Action Plan." Last modified May 29, 2003. http://www.fsa.gov.uk/library/communication/speeches/2003/sp131.shtml

Guiso, Luigi, Tullio Jappelli, Mario Padula, Marco Pagano, Philippe Martin, and Pierre- 
Olivier Gourinchas. "Financial Market Integration and Economic Growth in the EU." Economic Policy 19 (40) (2004): 525-77.

Gupta, Nandini, and Kathy Yuan. "Financial Dependence, Stock Market Liberalizations, and Growth." William Davidson Working Paper 562 (2003):1-39.

Gupta, Nandini, and Kathy Yuan. "On the Growth Effect of Stock Market Liberalizations." Review of Financial Studies 22 (11) (2009): 4715-52.

Hartmann, Philipp, Angela Maddaloni, and Simone Manganelli. "The Euro Area Financial System: Structure, Integration and Policy Initiatives." European Central Bank Working Paper 230 (2003): 1-54.

HM Treasury, the Financial Services Authority, and the Bank of England. "The EU Financial Services Action Plan: A Guide.” (2003):1-24.

HM Treasury, the Financial Services Authority, and the Bank of England. "After the EU Financial Services Action Plan: A new strategic approach." (2004a):1-42.

HM Treasury, the Financial Services Authority, and the Bank of England. "The EU Financial Services Action Plan: Delivering the FSAP in the UK." (2004b):1-40.

Jayaratne, Jith, and Philip Strahan. "The Finance-Growth Nexus: Evidence from Bank Branch Deregulation.” Quarterly Journal of Economics 111 (3) (1996): 639-70.

Jayaratne, Jith, and Philip Strahan. "The Benefits of Branching Deregulation." Federal Reserve Bank of New York Economic Policy Review 3 (4) (1997): 13-29.

Kalemli - Ozcan, Sebnem, Elias Papaioannou, and Jose-Luis Peydro. "What Lies beneath the Euro's Effect on Financial Integration? Currency Risk, Legal Harmonization, or Trade?" Journal of International Economics 81 (1) (2010): 75-88.

Kalemli-Ozcan, Sebnem, Elias Papaioannou, and Jose-Luis Peydro. "Financial Regulation, Financial Globalization and the Synchronization of Economic Activity." Journal of Finance 68 (3) (2013): 1179-1220.

Klenow, Peter J. "Ideas versus rival human capital: Industry evidence on growth models." Journal of Monetary Economics 42 (1998): 3-23.

La Porta, Rafael, Florencio Lopez-de-Silanes, Andrei Shleifer, and Robert Vishny. "Legal Determinants of External Finance.” Journal of Finance 52 (3) (1997): 1131-50. 
La Porta, Rafael, Florencio Lopez-de-Silanes, Andrei Shleifer, and Robert Vishny. "Law and Finance.” Journal of Political Economy 106 (6) (1998): 1113-55.

La Porta, Rafael, Florenci Lopez-de-Silanes, and Andrei Shleifer. "The Economic Consequences of Legal Origins." Journal of Economic Literature 46 (2) (2008): 285332.

London Economics. "Quantification of the Macro-Economic Impact of Integration of EU Financial Markets. Executive Summary of the Final Report to the European Commission - Directorate-General for the Internal Market (2002):1-9.

Malcolm, Kyle, Mark Tilden, and Tim Wilsdon. "Evaluation of the economic impacts of the Financial Services Action Plan." European Commission Internal Market and Services Final Report (2009):1-242.

Morgan, Donald P., Bertrand Rime, and Philip Strahan. "Bank Integration and State Business Cycles." The Quarterly Journal of Economics 119 (4) (2004): 1555-1584.

Ozkok, Zeynep. "Financial Harmonization and Financial Development: An Application of Europe's Financial Services Action Plan." Applied Economics Quarterly. 62(1) (2016): $1-35$.

Rajan, Raghuram G, and L. Zingales. "Financial Dependence and Growth." American Economic Review 88 (3) (1998): 559-586.

Strahan, Philip. "The Real Effects of U.S. Banking Deregulation." Wharton Financial Institutions Center Working Paper Series 02 - 39 (2002):111 - 28.

Timmer, Marcel P., Ton van Moergastel, Edwin Stuivenwold, Gerard Ypma, Mary O'Mahony, and Mari Kangasniemi. "EU KLEMS Growth and Productivity Accounts, Version 1." EU KLEMS (2007):1-57.

Timmer, Marcel P., Mary O’Mahony, and Bart van Ark. "EU KLEMS Growth and Productivity Accounts: Overview November 2007 Release.” EU KLEMS (2007):1-18.

Worldwide Governance Indicators. “Aggregate Governance Indicators." The World Bank Group, Accessed April 22, 2017. http://info.worldbank.org/governance/wgi/index. aspx\#home 


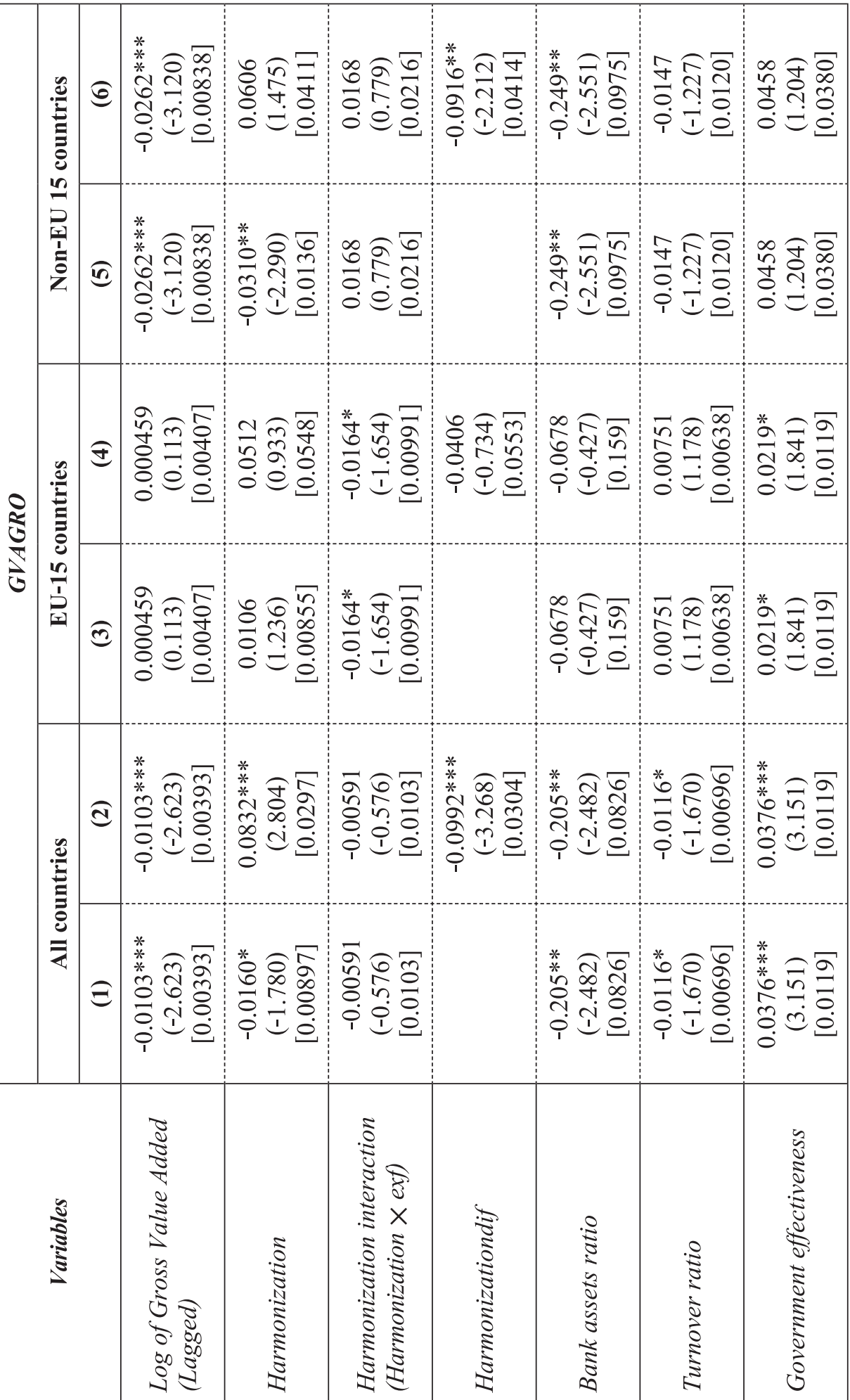




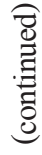

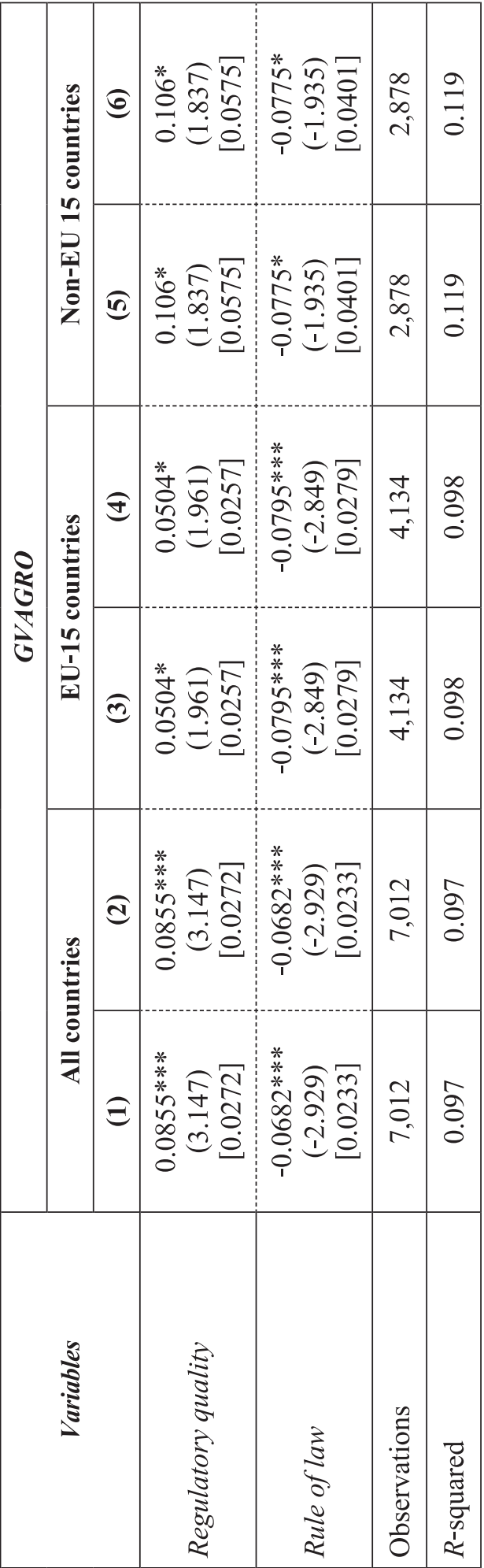

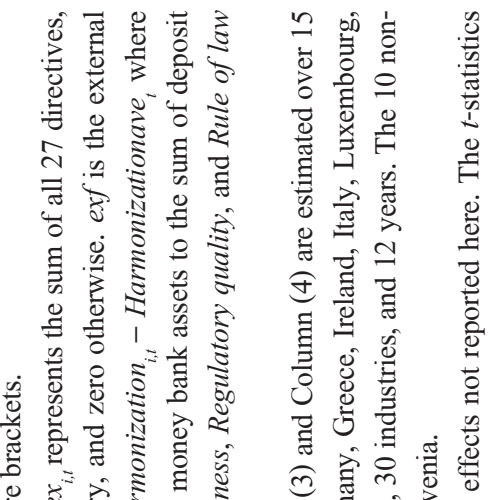

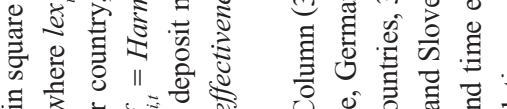

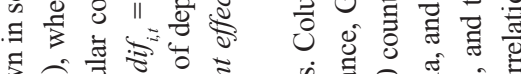

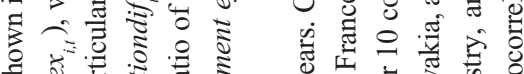

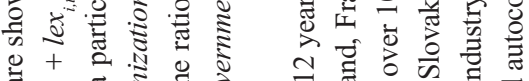

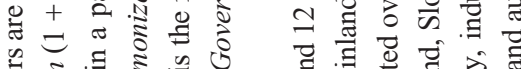

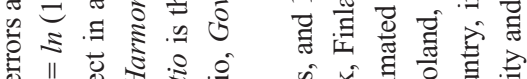

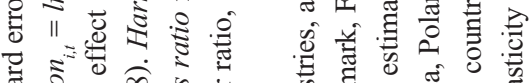

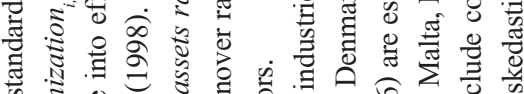
क

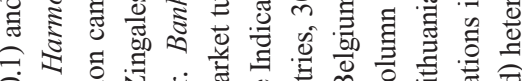

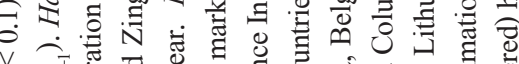
2 I

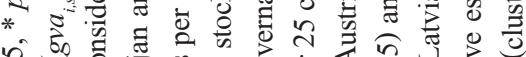

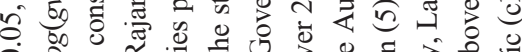

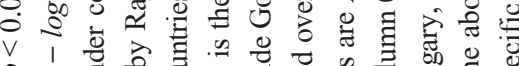

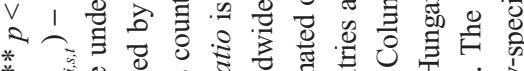
* ठ. ప్ $\checkmark$ 의 *

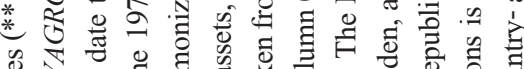

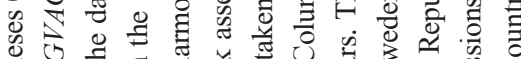

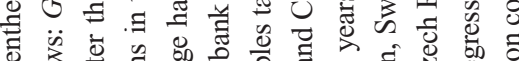

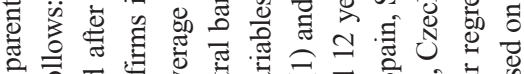

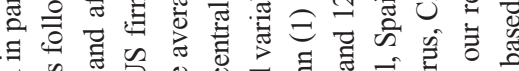

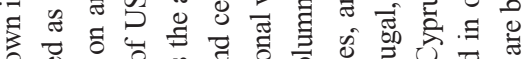

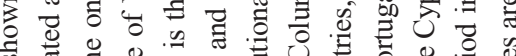
की

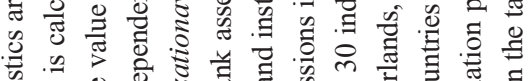

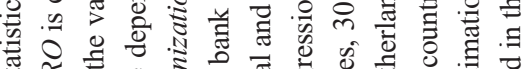

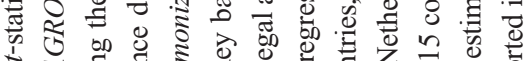

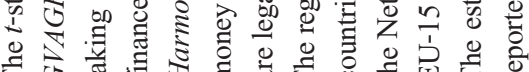

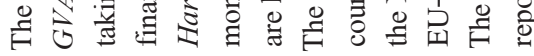
$\cong \cong$ 2) 


\section{Appendix 2: Financial harmonization and industrial growth}

(Arellano - Bond dynamic panel estimation with further controls)

\begin{tabular}{|c|c|c|c|c|c|}
\hline \multirow{3}{*}{ Variables } & \multicolumn{5}{|c|}{ GVAGRO } \\
\hline & \multirow{2}{*}{\begin{tabular}{|c|} 
All countries \\
$(1)$
\end{tabular}} & \multicolumn{2}{|c|}{ EU-15 countries } & \multicolumn{2}{|c|}{ Non-EU 15 countries } \\
\hline & & (2) & (3) & (4) & (5) \\
\hline $\begin{array}{l}\text { Gross Value Added Growth } \\
\text { (Lagged) }\end{array}$ & $\begin{array}{c}-0.936^{* * *} \\
(-3.299) \\
{[0.284]}\end{array}$ & $\begin{array}{c}-0.765^{*} \\
(-1.648) \\
{[0.464]}\end{array}$ & $\begin{array}{c}-0.785 * \\
(-1.676) \\
{[0.469]}\end{array}$ & $\begin{array}{c}-0.457 \\
(-1.379) \\
{[0.332]}\end{array}$ & $\begin{array}{c}-0.329 \\
(-1.007) \\
{[0.327]}\end{array}$ \\
\hline Harmonization & $\begin{array}{c}0.207 * * \\
(2.101) \\
{[0.0987]}\end{array}$ & $\begin{array}{c}-0.0144 \\
(-0.245) \\
{[0.0588]}\end{array}$ & $\begin{array}{c}0.000137 \\
(0.00799) \\
{[0.0172]}\end{array}$ & $\begin{array}{c}0.0205 \\
(0.345) \\
{[0.0596]}\end{array}$ & $\begin{array}{c}0.0448 * \\
(1.714) \\
{[0.0262]}\end{array}$ \\
\hline $\begin{array}{l}\text { Harmonization interaction } \\
(\text { Harmonization } \times \text { exf })\end{array}$ & $\begin{array}{c}-0.131 \\
(-1.174) \\
{[0.112]}\end{array}$ & $\begin{array}{c}-0.0671 \\
(-0.687) \\
{[0.0976]}\end{array}$ & $\begin{array}{l}-0.0509 \\
(-0.646) \\
{[0.0787]}\end{array}$ & $\begin{array}{c}-0.214 \\
(-1.338) \\
{[0.160]}\end{array}$ & $\begin{array}{c}-0.245 \\
(-1.571) \\
{[0.156]}\end{array}$ \\
\hline Harmonizationdif & $\begin{array}{c}-0.350 * * \\
(-2.382) \\
{[0.147]}\end{array}$ & $\begin{array}{c}-0.00893 \\
(-0.114) \\
{[0.0781]}\end{array}$ & $\begin{array}{c}-0.0189 \\
(-0.281) \\
{[0.0673]}\end{array}$ & $\begin{array}{l}0.0339 \\
(0.129) \\
{[0.262]}\end{array}$ & $\begin{array}{c}-0.296 * * * \\
(-2.830) \\
{[0.105]}\end{array}$ \\
\hline Bank assets & $\begin{array}{c}-11.99 * * \\
(-2.221) \\
{[5.399]}\end{array}$ & $\begin{array}{c}-0.990 \\
(-0.245) \\
{[4.046]}\end{array}$ & $\begin{array}{c}-1.354 \\
(-1.225) \\
{[1.105]}\end{array}$ & $\begin{array}{c}0.189 \\
(0.0913) \\
{[2.065]}\end{array}$ & $\begin{array}{c}-0.956 \\
(-1.414) \\
{[0.677]}\end{array}$ \\
\hline Turnover ratio & $\begin{array}{l}0.00177 \\
(0.0318) \\
{[0.0557]}\end{array}$ & $\begin{array}{c}-0.0134 \\
(-0.238) \\
{[0.0565]}\end{array}$ & $\begin{array}{l}-0.0275 \\
(-0.426) \\
{[0.0645]}\end{array}$ & $\begin{array}{l}0.0599 \\
(0.376) \\
{[0.159]}\end{array}$ & $\begin{array}{c}-0.0637 \\
(-0.591) \\
{[0.108]}\end{array}$ \\
\hline Government Effectiveness & $\begin{array}{c}0.236 * * * \\
(2.719) \\
{[0.0866]}\end{array}$ & $\begin{array}{l}-0.0115 \\
(-0.157) \\
{[0.0733]}\end{array}$ & $\begin{array}{c}-0.00219 \\
(-0.0671) \\
{[0.0326]}\end{array}$ & $\begin{array}{c}0.924 \\
(1.559) \\
{[0.593]}\end{array}$ & $\begin{array}{c}0.169 \\
(1.444) \\
{[0.117]}\end{array}$ \\
\hline Regulatory quality & $\begin{array}{c}-0.290 \\
(-0.681) \\
{[0.426]}\end{array}$ & $\begin{array}{c}0.592 \\
(1.578) \\
{[0.375]}\end{array}$ & $\begin{array}{c}0.535^{* *} \\
(2.497) \\
{[0.214]}\end{array}$ & $\begin{array}{c}-0.0382 \\
(-0.0545) \\
{[0.701]}\end{array}$ & $\begin{array}{c}-0.226 \\
(-0.444) \\
{[0.508]}\end{array}$ \\
\hline Rule of law & $\begin{array}{c}0.890 \\
(1.577) \\
{[0.564]}\end{array}$ & $\begin{array}{c}-0.205 \\
(-0.428) \\
{[0.480]}\end{array}$ & $\begin{array}{c}-0.179 \\
(-0.640) \\
{[0.280]}\end{array}$ & $\begin{array}{c}-0.636 \\
(-1.289) \\
{[0.494]}\end{array}$ & $\begin{array}{c}-0.329 \\
(-0.704) \\
{[0.468]}\end{array}$ \\
\hline Observations & 6,134 & 3,544 & 3,380 & 2,590 & 2,561 \\
\hline Number of groups & 708 & 424 & 403 & 284 & 284 \\
\hline $\mathrm{AB}$ test for $\mathrm{AR}(1)$ ( $p$-value) & $\begin{array}{c}0.73 \\
(0.464)\end{array}$ & $\begin{array}{c}-0.21 \\
(0.837)\end{array}$ & $\begin{array}{c}-0.14 \\
(0.885)\end{array}$ & $\begin{array}{c}-1.04 \\
(0.300)\end{array}$ & $\begin{array}{c}-0.91 \\
(0.365)\end{array}$ \\
\hline $\mathrm{AB}$ test for $\mathrm{AR}(2)$ ( $p$-value) & $\begin{array}{c}-0.72 \\
(0.470)\end{array}$ & $\begin{array}{c}-1.66 \\
(0.097)\end{array}$ & $\begin{array}{l}-1.60 \\
(0.109)\end{array}$ & $\begin{array}{c}-1.15 \\
(0.251)\end{array}$ & $\begin{array}{c}-1.13 \\
(0.259)\end{array}$ \\
\hline
\end{tabular}


(continued)

\begin{tabular}{|l|c|c|c|c|c|}
\hline \multirow{3}{*}{\multicolumn{1}{|c|}{ Variables }} & \multicolumn{5}{|c|}{ GVAGRO } \\
\cline { 2 - 6 } & All countries & EU-15 countries & Non-EU 15 countries \\
\cline { 2 - 6 } & $\mathbf{( 1 )}$ & $\mathbf{( 2 )}$ & $\mathbf{( 3 )}$ & $\mathbf{( 4 )}$ & $\mathbf{( 5 )}$ \\
\hline Sargan test & 0.203 & 0.177 & 0.505 & 0.060 & 0.027 \\
\hline Hansen test & 0.367 & 0.401 & 0.622 & 0.115 & 0.192 \\
\hline
\end{tabular}

(Note) (i) The $t$-statistics are shown in parentheses $(* * * p<0.01, * * p<0.05, * p<0.1)$ and standard errors are shown in square brackets.

(ii) GVAGRO is calculated as follows: $G V A G R O=\log \left(g v a_{i, s, t}\right)-\log \left(g v a_{i, s, t-1}\right)$. Harmonization ${ }_{i, t}=\ln$ $\left(1+\right.$ lex $\left._{i, t}\right)$, where $l e x_{i, t}$ represents the sum of all 27 directives, taking the value one on and after the date the directive under consideration came into effect in a particular country, and zero otherwise. exf is the external finance dependence of US firms in the 1970s, calculated by Rajan and Zingales (1998). Harmonizationdif $f_{i, t}=$ Harmonization $_{i, t}-$ Harmonizationave $_{t}$ where Harmonizationave is $_{t}$ the average harmonization across countries per year. Bank assets ratio is the ratio of deposit money bank assets to the sum of deposit money bank assets and central bank assets, Turnover ratio is the stock market turnover ratio, Government effectiveness, Regulatory quality, and Rule of law are legal and institutional variables taken from the Worldwide Governance Indicators.

(iii) The regression in Column (1) is estimated over 25 countries, 30 industries, and 12 years. Column (2) is estimated over 15 countries, 30 industries, and 12 years. The EU-15 countries are Austria, Belgium, Denmark, Finland, France, Germany, Greece, Ireland, Italy, Luxembourg, the Netherlands, Portugal, Spain, Sweden, and the UK. Column (3) and Column (4) are estimated over 10 countries, 30 industries, and 12 years. The 10 non-EU-15 countries are Cyprus, Czech Republic, Estonia, Hungary, Latvia, Lithuania, Malta, Poland, Slovakia, and Slovenia.

(iv) The estimation period in our regressions is 1996 2007. All regressions are estimated using the Arellano-Bond dynamic panel GMM estimation with one lag of the dependent variable included in the model. All columns use the 4th lag of the logarithm of gross value-added as GMM-type instruments. Column (1), Column (2), and Column (4) use political stability measure from World Governance Indicators data set, first lag of the harmonization index, first lag of the interaction term, and the time dummies as IV-type instruments. Column (3), in addition to these IV-type instruments, employs the ratio of deposit money bank assets to the sum of deposit money bank and central bank assets, as well as government effectiveness as instruments. Column (5) introduces the ratio of deposit money bank assets to the sum of deposit money bank and central bank assets, and government effectiveness and the stock market turnover ratio as instruments. The results reported here use the one-step estimator (estimations use the Stata "xtabond2" command). 